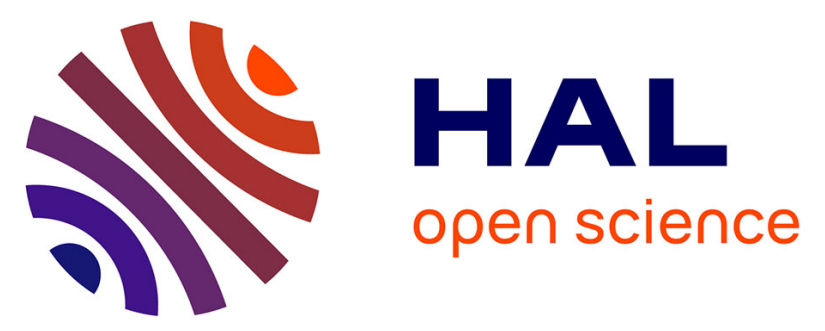

\title{
Synthesis of Symmetrical and Unsymmetrical 1,3-Diheteroarylbenzenes Through Palladium-Catalyzed Direct Arylation of Benzene-1,3-disulfonyl Dichloride and 3-Bromobenzenesulfonyl Chlorides
}

Imane Idris, Fazia Derridj, Safia Djebbar, Jean-François Soulé, Henri Doucet

\section{To cite this version:}

Imane Idris, Fazia Derridj, Safia Djebbar, Jean-François Soulé, Henri Doucet. Synthesis of Symmetrical and Unsymmetrical 1,3-Diheteroarylbenzenes Through Palladium-Catalyzed Direct Arylation of Benzene-1,3-disulfonyl Dichloride and 3-Bromobenzenesulfonyl Chlorides. Tetrahedron, 2015, 71 (52), pp.9617-9625. 10.1016/j.tet.2015.10.082 . hal-01224511

HAL Id: hal-01224511

https://hal-univ-rennes1.archives-ouvertes.fr/hal-01224511

Submitted on 2 Dec 2015

HAL is a multi-disciplinary open access archive for the deposit and dissemination of scientific research documents, whether they are published or not. The documents may come from teaching and research institutions in France or abroad, or from public or private research centers.
L'archive ouverte pluridisciplinaire HAL, est destinée au dépôt et à la diffusion de documents scientifiques de niveau recherche, publiés ou non, émanant des établissements d'enseignement et de recherche français ou étrangers, des laboratoires publics ou privés. 


\section{Graphical Abstract}

\section{Synthesis of Symmetrical and}

Unsymmetrical 1,3-Diheteroarylbenzenes

Through Palladium-Catalyzed Direct

Arylation of Benzene-1,3-disulfonyl

Dichloride and 3-Bromobenzenesulfonyl

Chlorides

I. Idris, F. Derridj, S. Djebbar, J.-F. Soulé, H. Doucet

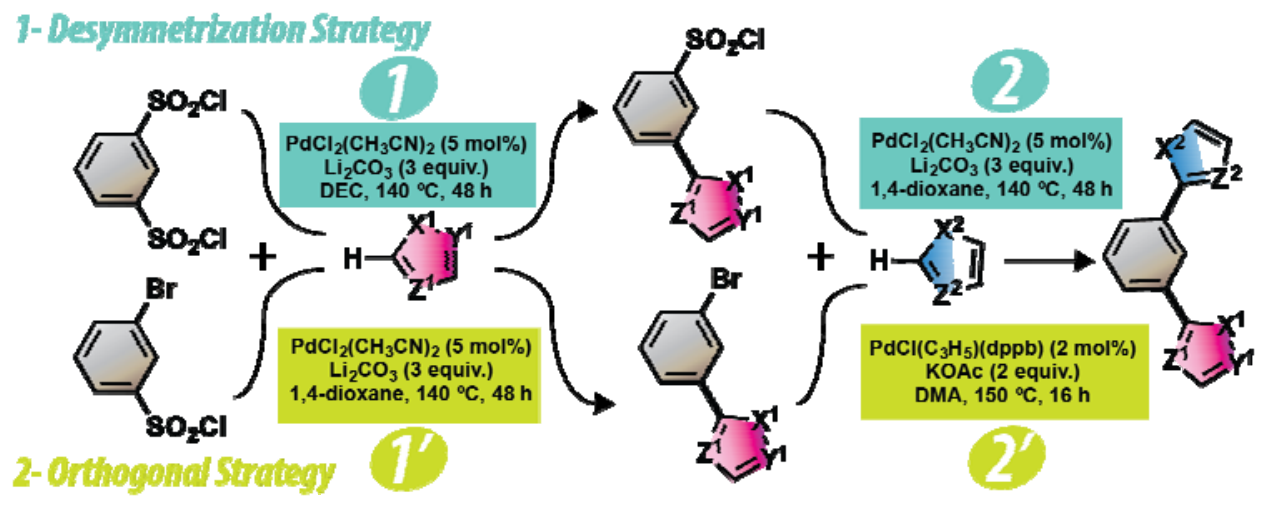




\title{
Synthesis of Symmetrical and Unsymmetrical 1,3-Diheteroarylbenzenes Through Palladium-Catalyzed Direct Arylation of Benzene-1,3-disulfonyl Dichloride and 3-Bromobenzenesulfonyl Chlorides
}

\author{
Imane Idris, ${ }^{\text {a, b }}$ Fazia Derridj, ${ }^{\text {a, b, c }}$ Safia Djebbar, ${ }^{c}$ Jean-François Soulé, ${ }^{\text {a }}$ * and Henri Doucet ${ }^{\text {a, }}$ * \\ ${ }^{a}$ Institut des Sciences Chimiques de Rennes, UMR 6226 CNRS-Université de Rennes 1 "Organométalliques, Matériaux et Catalyse", Campus de Beaulieu, 35042 \\ Rennes, France \\ ${ }^{b}$ Département de chimie, UMMTO, University, BP 17 RP, 15000 Tizi-Ouzou, Algeria \\ ${ }^{c}$ Laboratoire d'hydrométallurgie et chimie inorganique moléculaire, Faculté de Chimie, U.S.T.H.B. Bab-Ezzouar, Algeria.
}

\section{ABSTRACT}

The palladium-catalyzed synthesis of unsymmetrical 1,3-diheteroarylbenzenes was investigated. The first synthetic pathway relies on the desymmetrization of benzene-1,3-disulfonyl dichloride through two successive palladiumcatalyzed direct desulfitative arylations with two different heteroarenes. The second strategy employs the orthogonal functionalization of 3-bromobenzenesulfonylchloride using an iterative $\mathrm{C}-\mathrm{H}$ bond arylation sequence, namely, palladium-catalyzed direct desulfitative arylation followed by a palladium-catalyzed direct arylation step using aryl bromide as the coupling partner. The synthesis of symmetrical 1,3-diheteroarylbenzenes was also investigated.

Keywords:

C-H Arylation, Catalysis, Desulfitative, Tridentate Ligand, Palladium

\section{Introduction}

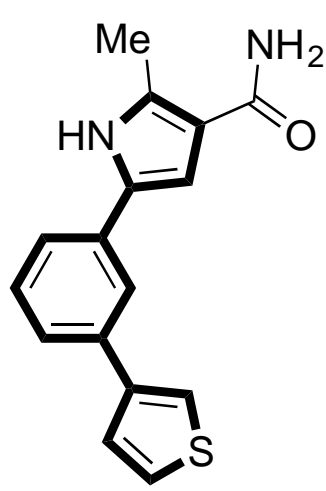

I

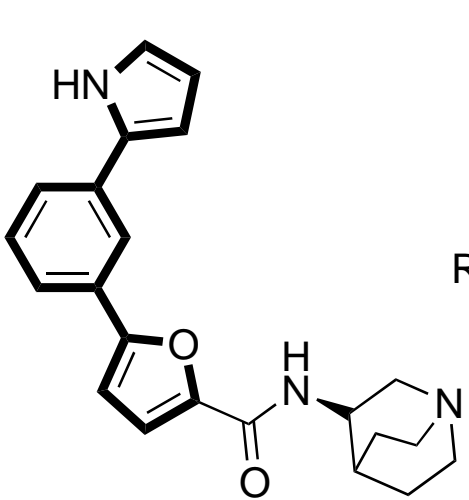

II

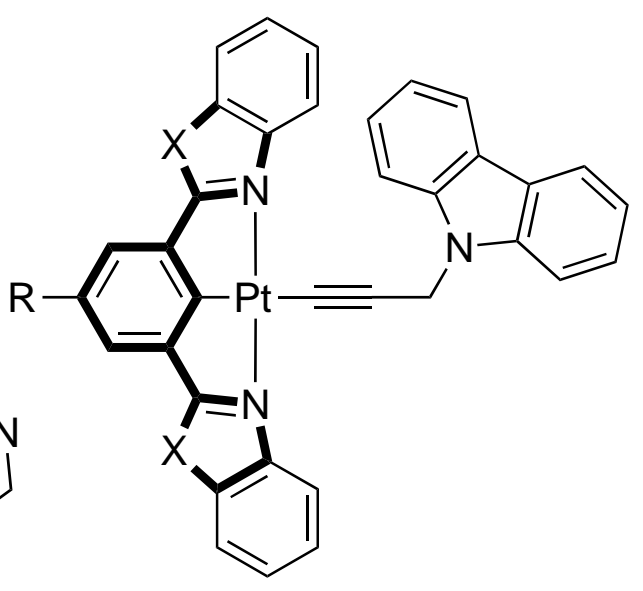

$\mathrm{X}=\mathrm{O}, \mathrm{S}$, or NAlkyl

III

Figure 1. Examples of uses of 1,3-diheteroarylbenzenes.

1,3-Diheteroarylbenzenes are an important class of molecules in organic chemistry. Unsymmetrical 1,3diheteroarylbenzenes, such as molecule I, which contains 3-thienyl and 2-pyrrolyl substituents, are useful agents in the treatment of diseases, including inflammatory diseases, cancer, and AIDS (Figure 1). ${ }^{1} \mathrm{~N}$-Quinuclidinyl-heteroaryl amide II, which contains both 2-furyl and 2-pyrrolyl moieties, has shown potential pharmaceutical uses in the

\footnotetext{
* Corresponding author. Tel.: +33(0) 2232332 06; e-mail: jean-francois.soule@univ-rennes1.fr

* Corresponding author. Tel.: +33(0) 2232363 84; e-mail: henri.doucet@univ-rennes1.fr
} 
treatment of neurological disorders (Figure 1). ${ }^{2}$ Moreover, they are ubiquitous subunits embedded in number of tridentate ligands such as $\mathrm{N}^{\wedge} \mathrm{C}^{\wedge} \mathrm{N}$, which found many applications in electronic devices or in catalysis.

For example, the family of complexes III, based on 1,3-bis-heteroazolylbenzenes ligand, displays tunable color luminescent properties, which has plenty of applications in the construction of organic light-emitting (OLED) devices (Figure 1). ${ }^{4}$ 1,3-Diheteroarylbenzenes are generally synthesized from isophthalaldehydes via a double condensation with 2-aminophenols or 2-aminobenzenethiols (Figure 2A). ${ }^{5}$ However, this methodology is limited to the synthesis of symmetrical compounds. A few examples of preparation of unsymmetrical 1,3-diheteroarylbenzenes have been reported starting from 3-bromobenzaldehydes via a condensation of the aldehyde function with amines followed by palladium-catalyzed $\mathrm{C}-\mathrm{C}$ bond formation (e.g., Negishi or Suzuki reactions) (Figure 2B). ${ }^{6}$ An other synthetic pathway involved double palladium-catalyzed $\mathrm{C}-\mathrm{C}$ bond formation using 1,3-dibromobenzene and organometallic reagents (Figure 2C). ${ }^{7}$ This methodology is limited to the synthesis of symmetrical compounds, albeit some reports focused on the desymmetrization of 1,3-dibromobenzene using selective mono-coupling based on Suzuki reaction. ${ }^{8}$ Dodd and co-workers reported the synthesis of unsymmetrical 1,3-diheteroarylbenzenes using an one-pot procedure involving double Suzuki reaction with two different boronic acids. ${ }^{9}$ Since these last decades, palladium-catalyzed direct arylation has emerged as one of the most eco-friendly methods for the fast synthesis of complex molecules. ${ }^{10}$ Thanks to this methodology, we recently synthesized symmetrical 1,3-diheteroarylbenzenes from 1,3dibromobenzenes (Figure 2C). ${ }^{11}$ However, this synthetic pathway does not allow the synthesis of unsymmetrical compounds due to the very high reactivity of 1,3-dibromobenzenes. Recently, based on the pioneering works reported by Dong and co-workers, ${ }^{12}$ our group and others have exploited the reactivity of benzenesulfonyl chlorides for direct regioselective arylation of several heteroarenes. ${ }^{13}$ Similar desulfitative direct arylations were also reported using of sodium arylsulfinates, ${ }^{14}$ and arylsulfonyl hydrazides. ${ }^{15}$ It generally displays high reactivities and regioselectivities with good tolerances to $\mathrm{C}-\mathrm{X}$ bonds. ${ }^{16}$ In addition, the $\beta$-regioselectivity for the arylation of (benzo)thiophenes is an important advantage compared to other arylating agents. ${ }^{17}$ In the course of our investigations, we found that the desulfitative $\mathrm{C}-\mathrm{H}$ bond arylations were highly dependent to the benzenesulfonyl chloride electronic properties. As electron-poor benzenesulfonyl chlorides react faster than electron-rich ones, we assumed that with such reactants it should be possible to desymmetrize benzene-1,3-disulfonyl dichloride to allow the synthesis of unsymmetrical 1,3-diheteroarylbenzenes. Indeed, sulfonyl chloride has an electron-withdrawing character in contrast to heteroarenes which have electron-donating characters; hence the first desulfitative arylation should be faster than the second one. (Figure 2D). Moreover, thanks to the orthogonal reactivity of desulfitative $\mathrm{C}-\mathrm{H}$ bond arylations, which tolerates $\mathrm{C}-\mathrm{Br}$ bonds, we proposed a new synthetic approach to the construction of unsymmetrical 1,3-diheteroarylbenzenes from 3-bromobenzenesulfonyl chlorides through iterative direct arylations (Figure 1E).<smiles>C=CCCCC=C</smiles><smiles>C=Cc1ccccc1</smiles>
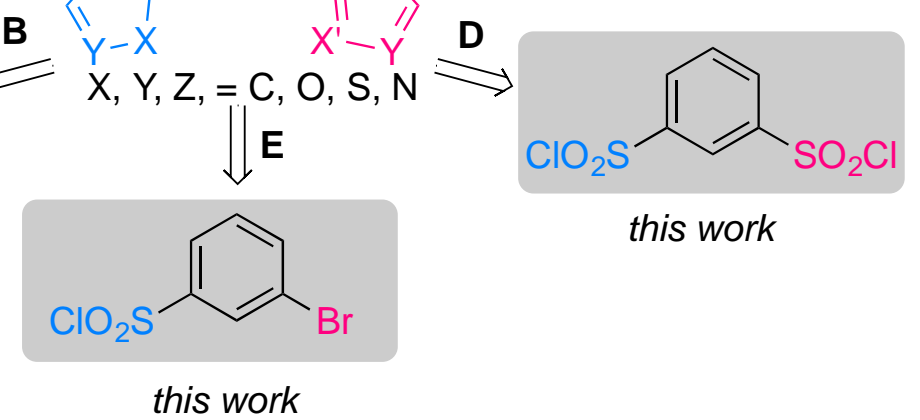

this work

Figure 2. Retrosynthetic pathways of 1,3-diheteroarylbenzenes.

\section{Results and Discussion.}

We started our investigation by studying the reactivity of benzene-1,3-disulfonyl dichloride as arylating source for the $\mathrm{C}-\mathrm{H}$ bond arylation of 2-n-butylfuran (Table 1). First, we attempted to prepare the monoarylated product 1 using our previous optimized reaction conditions for the $\mathrm{C}-\mathrm{H}$ bond arylation of furans, ${ }_{13 \mathrm{~d}}$ (i.e., $5 \mathrm{~mol} \%$ of $\mathrm{PdCl}_{2}\left(\mathrm{CH}_{3} \mathrm{CN}\right)_{2}$ in the presence of $\mathrm{Li}_{2} \mathrm{CO}_{3}$ as base in 1,4-dioxane at $140{ }^{\circ} \mathrm{C}$ during $48 \mathrm{~h}$ ) with a slight excess amount of benzene-1,3disulfonyl dichloride (1.5 equiv.). As result, we obtained a mixture of monoarylated and diarylated products $\mathbf{1}$ and 2 in 45:55 ratio (Table 1 , entry 1 ). To improve the yield in $\mathbf{1}$, both the solvent influence and the temperature were screened. We had previously demonstrated that the reaction could also be performed in green solvents such as diethyl carbonate (DEC) or cyclopentylmethyl ether (CPME) with comparable yields but with a lower reaction rates. ${ }^{18}$ When the reaction was performed in DEC, the monoarylation product $\mathbf{1}$ was obtained in $95 \%$ selectivity with a full conversion of 2-n-butylfuran (Table 1, entry 2). A lower selectivity and reactivity was observed using CPME as solvent ( $87 \%$ of 1 ) (Table 1 , entry 3$)$. The use of 1,4 -dioxane at only $110^{\circ} \mathrm{C}$ and a shorter reaction time $(18 \mathrm{~h})$ 
also furnished a high selectivity in favor of the monoarylated product 1 (Table 1, entry 4). No reaction occurred using polar and protic solvent such as DMF or butan-1-ol (Table 1, entries 5 and 6). Using these two optimized reaction conditions, i.e., DEC at $140^{\circ} \mathrm{C}$ during $48 \mathrm{~h}$ and 1,4-dioxane at $110^{\circ} \mathrm{C}$ during $18 \mathrm{~h}$, we achieved the synthesis of $\mathbf{1}$ in very high yield $(85-87 \%)^{19}$ using only 1.2 equivalents of benzene-1,3-disulfonyl dichloride (Table 1, entries 7 and 8). It is important to note that the use of a lower amount of benzene-1,3-disulfonyl dichloride (1.1 equiv.) gave a slightly lower 1:2 ratio (Table 1, entry 9). On the other hand, the diarylated product 2 has also been synthesized in high yield using 3 equivalents of 2 -n-butylfuran and 6 equivalents of base in 1,4-dioxane as solvent at $140{ }^{\circ} \mathrm{C}$ during $48 \mathrm{~h}$ (Table 1, entry 10).

Table 1. Effect of the reaction conditions on Pd-catalyzed desulfitative coupling of benzene-1,3-disulfonyl dichloride with 2-n-butylfuran.

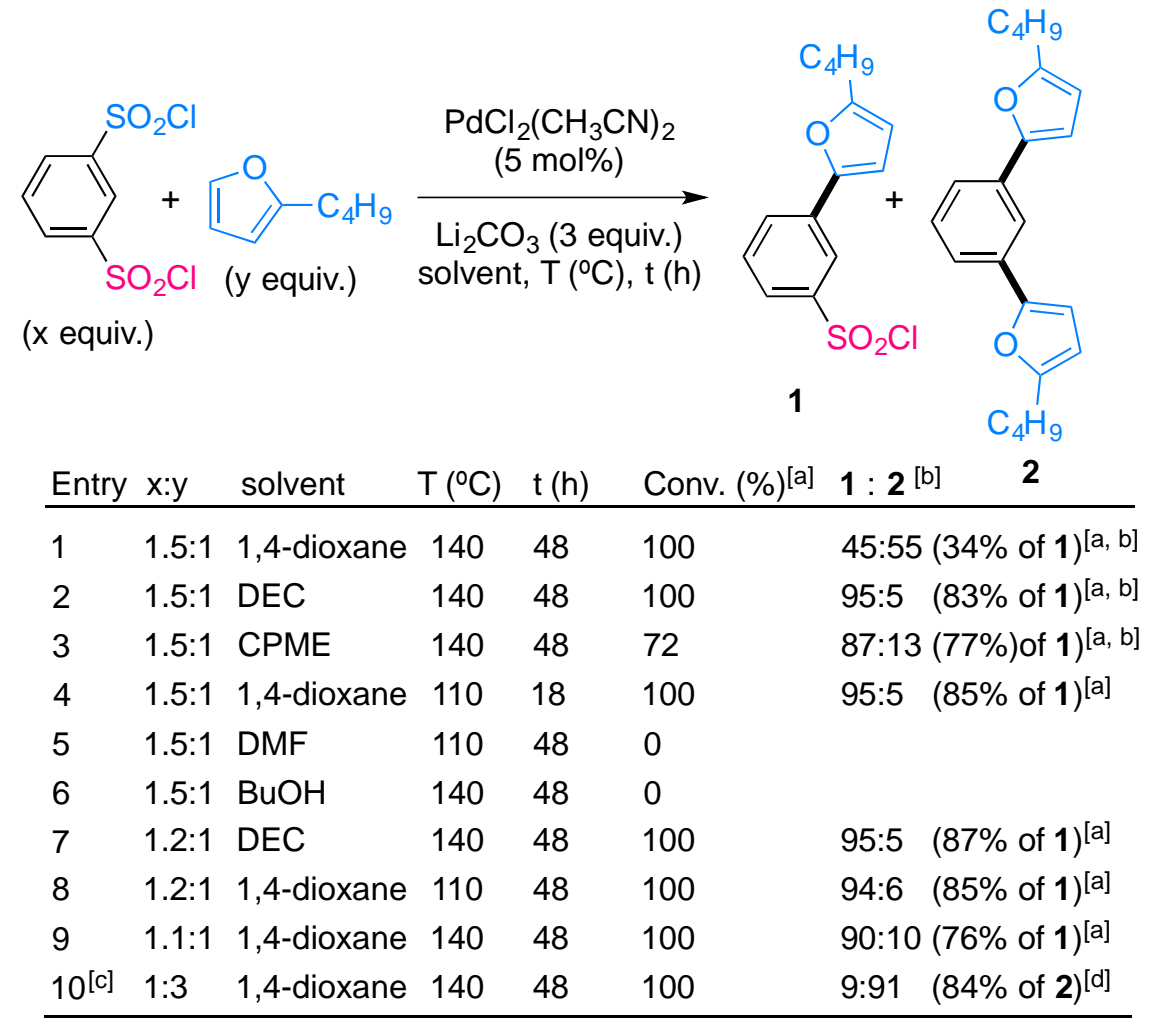

[a] Based on 2-n-butylfuran; [b] Determined using GC-MS and ${ }^{1} \mathrm{H}$ - NMR analyses, [c] 6 equiv. of $\mathrm{Li}_{2} \mathrm{CO}_{3}$ were used. [d] based on benzene-1,3disulfonyl dichloride

Next, we performed similar experiments with 1,3-dibromobenzene as the aryl source using $0.5 \mathrm{~mol} \%$ of $\mathrm{Pd}(\mathrm{OAc})_{2}$ in the presence of KOAc as base in DMA at $150^{\circ} \mathrm{C}$ (Table 2). As seen previously, ${ }^{11 a}$, $\mathrm{Tb}$ this substrate is very reactive and 2 was obtained as the major product, except in the presence of a huge amount (5 equiv.) of 1,3dibromobenzene (Table 2, entries 1-3). However, the monoarylated product 3 was isolated only $52 \%$ yield. No reaction occurred at lower temperature $\left(110^{\circ} \mathrm{C}\right)$, and the use of DEC as solvent had almost no effect on the 3:2 selectivity (Table 2, entries 4 and 5). 
Table 2. Effect of the reaction conditions on Pd-catalyzed direct coupling 1,3-dibromobenzene with 2-n-butylfuran.

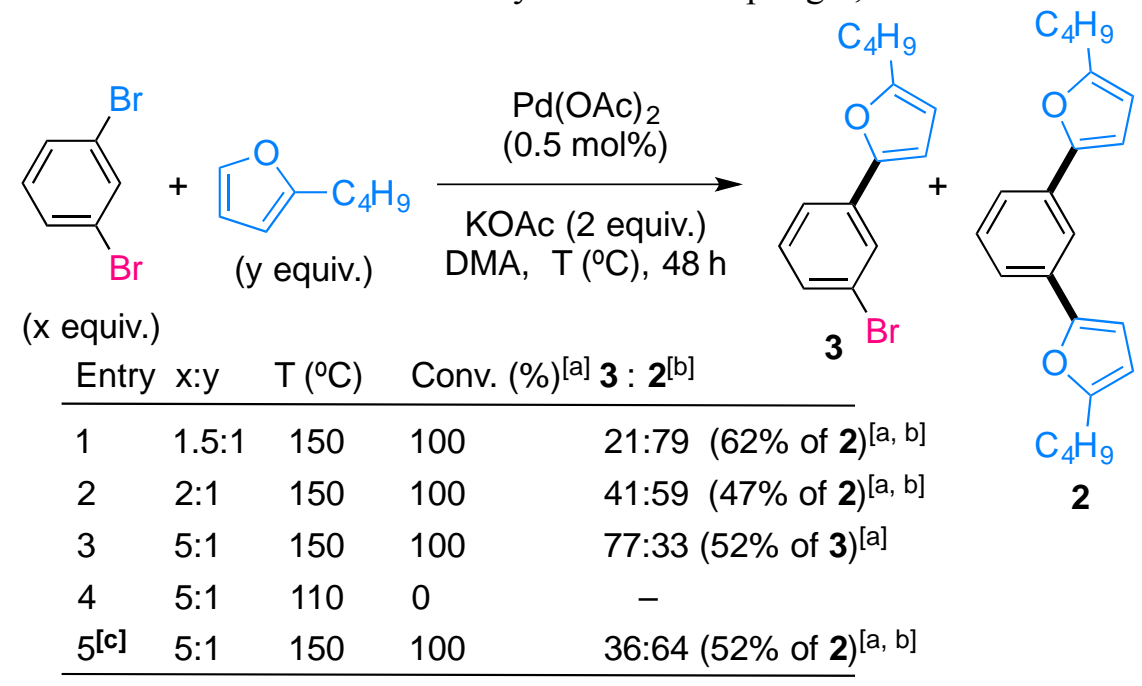

[a] Based on 2-n-butylfuran; [b] ratio determined using GC-MS and ${ }^{1} \mathrm{H}$ -

NMR analyses; [c] DEC was used as solvent.

In contrast to 1,3-dibromobenzene, we demonstrated that benzenedisulfonyl chloride could be easily desymmetrized and consequently it represents a suitable precursor of unsymmetrical 1,3-diheteroarylbenzenes. Then, we investigated the scope of the direct desulfitative monoarylation of benzene-1,3-disulfonyl dichloride with various heteroarenes in DEC at $140{ }^{\circ} \mathrm{C}$ (Scheme 1). 2-Furyl-2-propanone, which contains an enolizable ketone, was monoarylated to give 4 in $76 \%$ yield without any side reaction. The C2-regioselective direct arylation of benzofuran is challenging with other arylating partners. ${ }^{13 \mathrm{e}}$ From benzene-1,3-disulfonyl dichloride, 3-(benzofuran-2yl)benzenesulfonyl chloride (5) was isolated in 68\% yield. $N$-protected pyrroles were also suitable heteroarenes for the mono-desulfitative arylation, as 6 and 7 were obtained in $74 \%$ and $69 \%$ yields, respectively from 1-methylpyrrole and 1-phenylpyrrole. Thiophene derivatives displayed a $\beta$-regioselectivity but with a lower reactivity in such desulfitative coupling. To overcome this poor reactivity, we performed the reaction in 1,4-dioxane at $140{ }^{\circ} \mathrm{C}$ during $18 \mathrm{~h}$. Under these conditions, we were pleased to find that the reaction occurred, and from 2-methythiophene and 2bromothiophene the monoarylated products 8 and $\mathbf{9}$ were obtained in 58\% and $47 \%$ yields, respectively, without formation of diarylated products. Benzothiophene has also been used as heteroarene for the monodesulfitative arylation of benzene-1,3-disulfonyl dichloride to afford $\mathbf{1 0}$ in moderate yield. 
Scheme 1. Scope of the Pd-catalyzed direct desulfitative monoarylation of benzene-1,3-disulfonyl dichloride

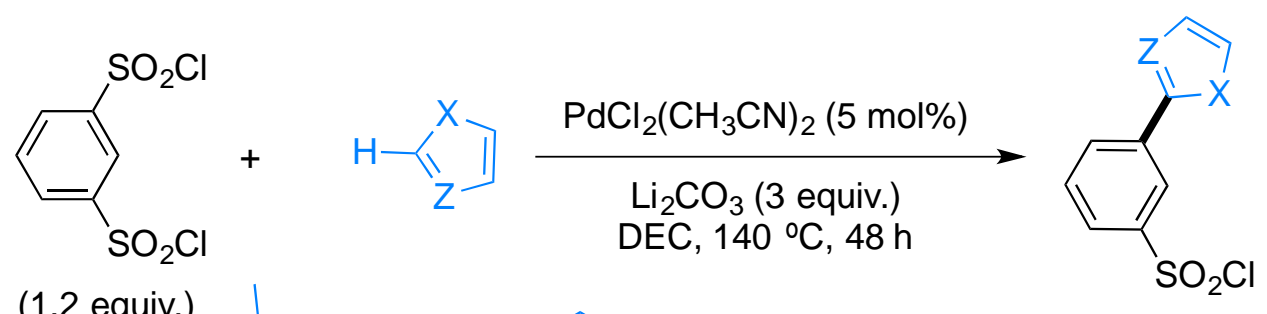<smiles>CC(=O)Cc1ccc(-c2cccc(S(=O)(=O)Cl)c2)o1</smiles>

$476 \%$<smiles>O=S(=O)(Cl)c1cccc(-c2cc3ccccc3o2)c1</smiles><smiles>Cn1cccc1-c1cccc(S(=O)(=O)Cl)c1</smiles><smiles>O=S(=O)(Cl)c1cccc(-c2cccn2-c2ccccc2)c1</smiles><smiles>Cc1cc(-c2cccc(S(=O)(=O)Cl)c2)cs1</smiles>

$568 \%$

$674 \%$<smiles>O=S(=O)(O)c1cccc(-c2csc3ccccc23)c1</smiles>

$812 \%(58 \%)^{[a, b]}$

$947 \%[a, b]$

$1063 \%[\mathrm{a}]$

[a] reaction was performed in 1,4-dioxane. [b] $18 \mathrm{~h}$.

As for all these selective monoarylations of benzene-1,3-disulfonyl dichloride, the second benzenesulfonyl chloride function remained untouched, we investigated the reactivity of 1, 5-8 in a second desulfitative direct arylation for the synthesis of unsymmetrical 1,3-diheteroarylbenzenes (Scheme 2). The synthesis of the unsymmetrical 1,3-diheteroarylbenzene $\mathbf{1 1}$ was achieved in 82\% yield from $\mathbf{1}$ and 1.5 equivalents of 1-methylpyrrole using the classical reaction conditions for desulfitative direct arylation, namely, 5 mol\% of $\mathrm{PdCl}_{2}\left(\mathrm{CH}_{3} \mathrm{CN}\right)_{2}$ in the presence of $\mathrm{Li}_{2} \mathrm{CO}_{3}$ as base in 1,4-dioxane at $140{ }^{\circ} \mathrm{C}$ during $48 \mathrm{~h}$. Using the same reaction conditions, the 3heteroarylbenzenesufonyl chloride 5 was converted into 12 in $73 \%$ yield. Then, a benzoxazole moiety was introduced on 6 and 7 to afford the desired compounds 13 and 14 in 68\% and 63\% yields, respectively. For these couplings, similar conditions to those reported by Cheng for the direct arylation of benzoxazole ${ }^{13 a}$-namely, the addition of a stoichiometric amount of copper to the reaction mixture- were used. Using this methodology, the benzene 15 bearing by two different pyrrole units (1-methyl- and 1-phenylpyrroles) was obtained in high yield. This approach also allowed the synthesis of a benzene meta disubstituted by thiophene and pyrrole units 16 in $81 \%$ yield. 
Scheme 2. Scope of the second desulfitative direct arylations: syntheses of unsymmetrical 1,3-diheteroarylbenzenes.<smiles>O=S(=O)(Cl)c1cccc(-c2[X]cc[c]2)c1</smiles><smiles>[H][Y]1ccccc1C</smiles>

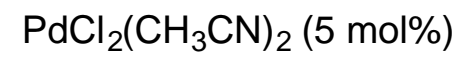
$\mathrm{Li}_{2} \mathrm{CO}_{3}$ (3 equiv.) (1.5 equiv.) 1,4-dioxane, $140^{\circ} \mathrm{C}, 48 \mathrm{~h}$<smiles></smiles>

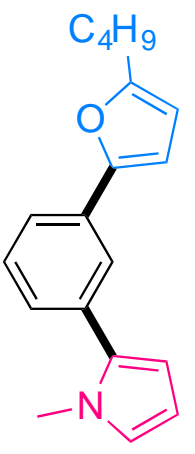<smiles>Cn1cccc1-c1cccc(-c2cc3ccccc3o2)c1</smiles><smiles>Cn1cccc1-c1cccc(-c2nc3ccccc3o2)c1</smiles><smiles>c1ccc(-n2cccc2-c2cccc(-c3nc4ccccc4o3)c2)cc1</smiles>

$1182 \%$ $1273 \%$ (from 1)<smiles>Cn1cccc1-c1cccc(-c2cccn2-c2ccccc2)c1</smiles>

\section{$1368 \%[\mathrm{a}]$ (from 6)} (from 5)

$1582 \%$ (from 7)

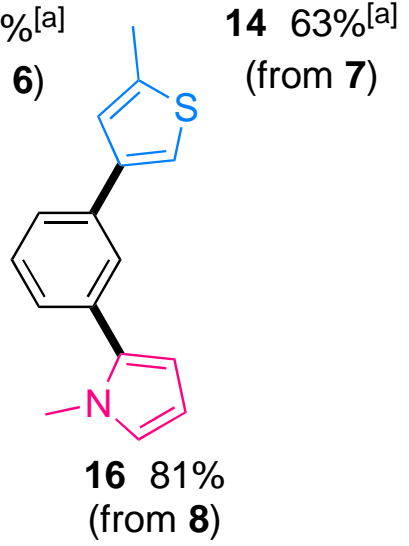

[a] Cul (1 equiv.) was used as additive.

(from 8)

Having successfully achieved the synthesis of unsymmetrical 1,3-diheteroarylbenzenes through two successive $\mathrm{C}-\mathrm{H}$ bond desulfitative arylations from benzene-1,3-disulfonyl dichloride, we turned our attention to the one-pot synthesis of symmetrical 1,3-diheteroarylbenzenes (Scheme 3). Using the optimized reaction conditions for the diarylation (Table 1, entry 8), the symmetrical compounds 17-21 were isolated in high yields. Notably, a larger excess of heteroarene was required in the case of 1-methylpyrrole in order to prevent the 2,5-diarylation of the pyrrole unit. $N$-benzylpyrrole was also tolerated affording 19 in $79 \%$ yield. 
Scheme 3. Scope of the one-pot Pd-catalyzed direct desulfitative diarylation of benzene-1,3-disulfonyl dichloride.<smiles>O=S(=O)(Cl)c1cccc(S(=O)(=O)Cl)c1</smiles><smiles>[H][Z]1[c]cc[c]1</smiles>

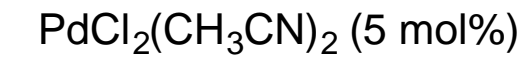
(3 equiv.) $\mathrm{Li}_{2} \mathrm{CO}_{3}$ (6 equiv.) 1,4-dioxane, $140^{\circ} \mathrm{C}, 48 \mathrm{~h}$<smiles>Cc1cc(-c2cccc(-c3csc(C)c3)c2)cs1</smiles><smiles>Cn1cccc1-c1cccc(-c2cccn2C)c1</smiles><smiles>c1ccc(Cn2cccc2-c2cccc(-c3cccn3Cc3ccccc3)c2)cc1</smiles><smiles>CC(=O)Cc1ccc(-c2cccc(-c3ccc(CC(C)=O)o3)c2)o1</smiles>

$1765 \%$ $1885 \%[\mathrm{a}]$ $1979 \%[a]$<smiles></smiles><smiles>c1cc(-c2cc3ccccc3o2)cc(-c2cc3ccccc3o2)c1</smiles>

$2175 \%$

[a] 5 equiv. of 1-methylpyrrole was used.

On the other hand, we had previously shown that palladium-catalyzed direct desulfitative arylation of heteroarenes was very chemoselective and we also demonstrated that the $\mathrm{C}-\mathrm{Br}$ bonds are not involved in the catalytic cycle, allowing orthogonal functionalizations. ${ }^{16}$ Here, we used the benefit of this unique chemoselectivity for the construction of unsymmetrical 1,3-diheteroarylbenzenes from 5-bromo-2-substituted benzenesulfonyl chlorides via two successive direct arylations (i.e., direct desulfitative arylation followed by direct arylation of the $\mathrm{C}-\mathrm{Br}$ bond) (Schemes 4 and 5). In a first step, we synthesized a set of 1-bromo-3-heteroarylbenzenes using the previous optimized conditions. In all case, no cleavage of the $\mathrm{C}-\mathrm{Br}$ bond was observed. The reaction between 2methylthiophene or 2-bromothiophene with 5-bromo-2-methylbenzenesulfonyl gave the challenging C3-arylated thiophenes 22 and 23 in $47 \%$ and 52\% yields, respectively. 1-Methylpyrrole was arylated at C2-position in 51\% yield. Using 1 equivalent of $\mathrm{CuI}$ as additive, the benzoxazole 24, in which the arylation occurred at $\mathrm{C} 1$ position, was isolated in $45 \%$ yield. A similar reactivity was observed using 5-bromo-2-methoxybenzenesulfonyl chloride as aryl source allowing the formation of the 1-bromo-3-heteroarylbenzene derivatives 26-28 in good yields. 
Scheme 4. Scope of the Pd-catalyzed desulfitative direct arylation with 5-bromo-2-methylbenzenesulfonyl chloride and 5-bromo-2-methoxybenzenesulfonyl chloride.
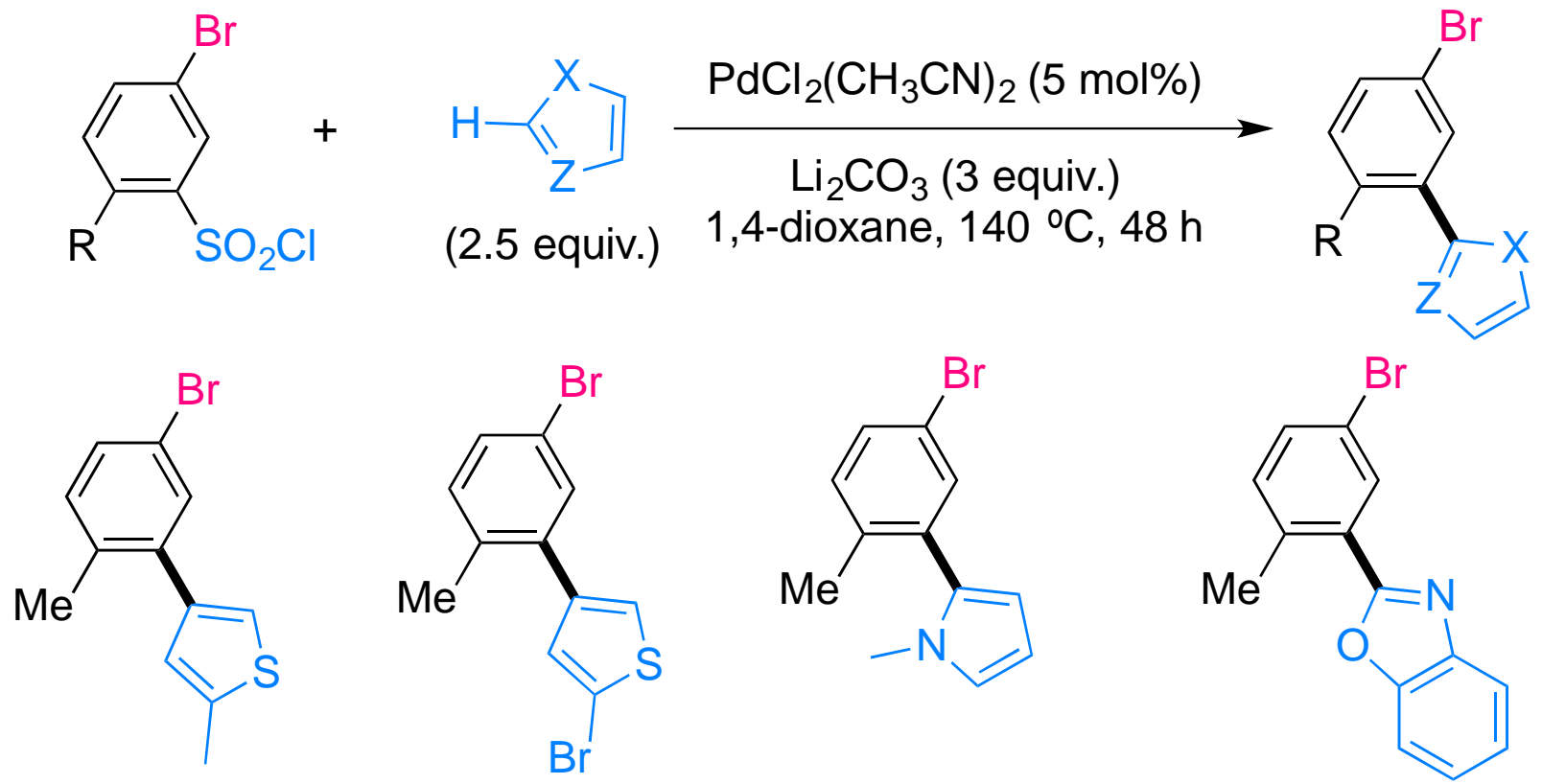

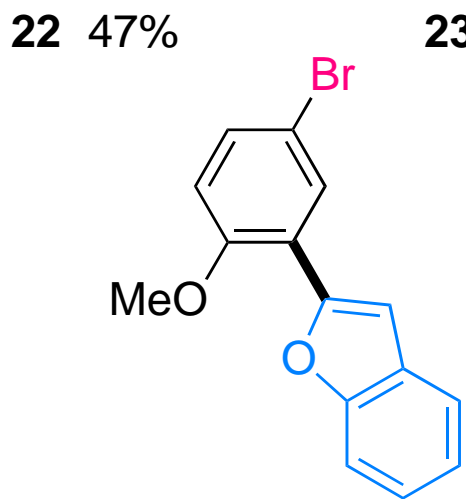

26 62\%
$2352 \%$

$2451 \%$<smiles>COc1ccc(Br)cc1-c1cccn1C</smiles>

$2774 \%$

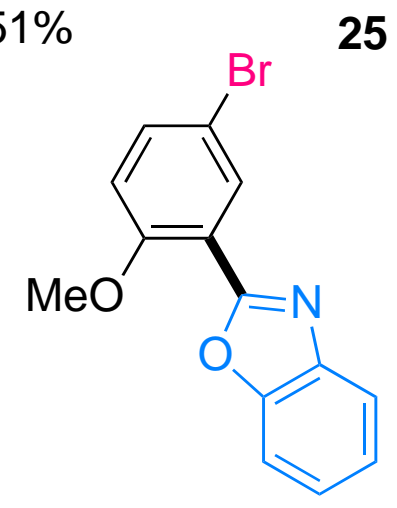

$2838 \%[a]$

\section{[a] Cul (1 equiv.) was used as additive}

After having performed the first desulfitative $\mathrm{C}-\mathrm{H}$ bond arylation, which gave 1-bromo-3-heteroarylbenzene derivatives 22-28, a second direct arylation was performed to deliver the targeted unsymmetrical 1,3-disubstituted benzenes (Scheme 5). We selected our previous reaction conditions, ${ }^{20}$ which have already demonstrated to be efficient for the direct arylation of heteroarenes with aryl bromides as coupling partners, i.e., 2 mol\% $\operatorname{PdCl}\left(\mathrm{C}_{3} \mathrm{H}_{5}\right)(\mathrm{dppb})$ catalyst [dppb $=1,4$-bis(diphenylphosphino)butane] in the presence of KOAc as base in dimethylacetamide (DMA) at $150{ }^{\circ} \mathrm{C}$ during $16 \mathrm{~h}$. When the direct arylation was performed with 22 or 24 as aryl bromide partners and benzoxazole, the desired 1,3-diheteroarylbenzenes 29 and $\mathbf{3 0}$ were obtained in excellent yields. We did not observe any homocoupling reaction, although the compounds 22 and 24 contain reactive $\mathrm{C}-\mathrm{H}$ bonds on the thienyl or pyrrolyl units. However, from the aryl bromide 23, which contains two different $\mathrm{C}-\mathrm{Br}$ bonds, we did not observe a chemoselective reaction, and an inseparable complex mixture of two mono-arylated and diarylated products was obtained. The aryl bromide 25 reacted with 2.5 equivalents of 4-ethyl-2-methylthiazole allowing the formation of the unsymmetrical 1,3-diheteroarylbenzene 31 in $84 \%$ yield. No major electronic effect of the aryl bromide was found in this reaction as 5-bromo-2-methoxybenzenesulfonyl chloride displays a similar reactivity than 5-bromo-2-methylbenzenesulfonyl chloride. Indeed, both unsymmetrical compounds $\mathbf{3 2}$ and $\mathbf{3 3}$ were synthesized in high yields. It is important to note that no homocoupling products of $\mathbf{2 6}$ and $\mathbf{2 7}$ resulting from an activation of pyrrolyl or benzofuranyl $\mathrm{C}-\mathrm{H}$ bonds were detected in the crude samples. 
Scheme 5. Scope of the Pd-catalyzed direct arylation with 1-bromo-3-heteroarylbenzene derivatives

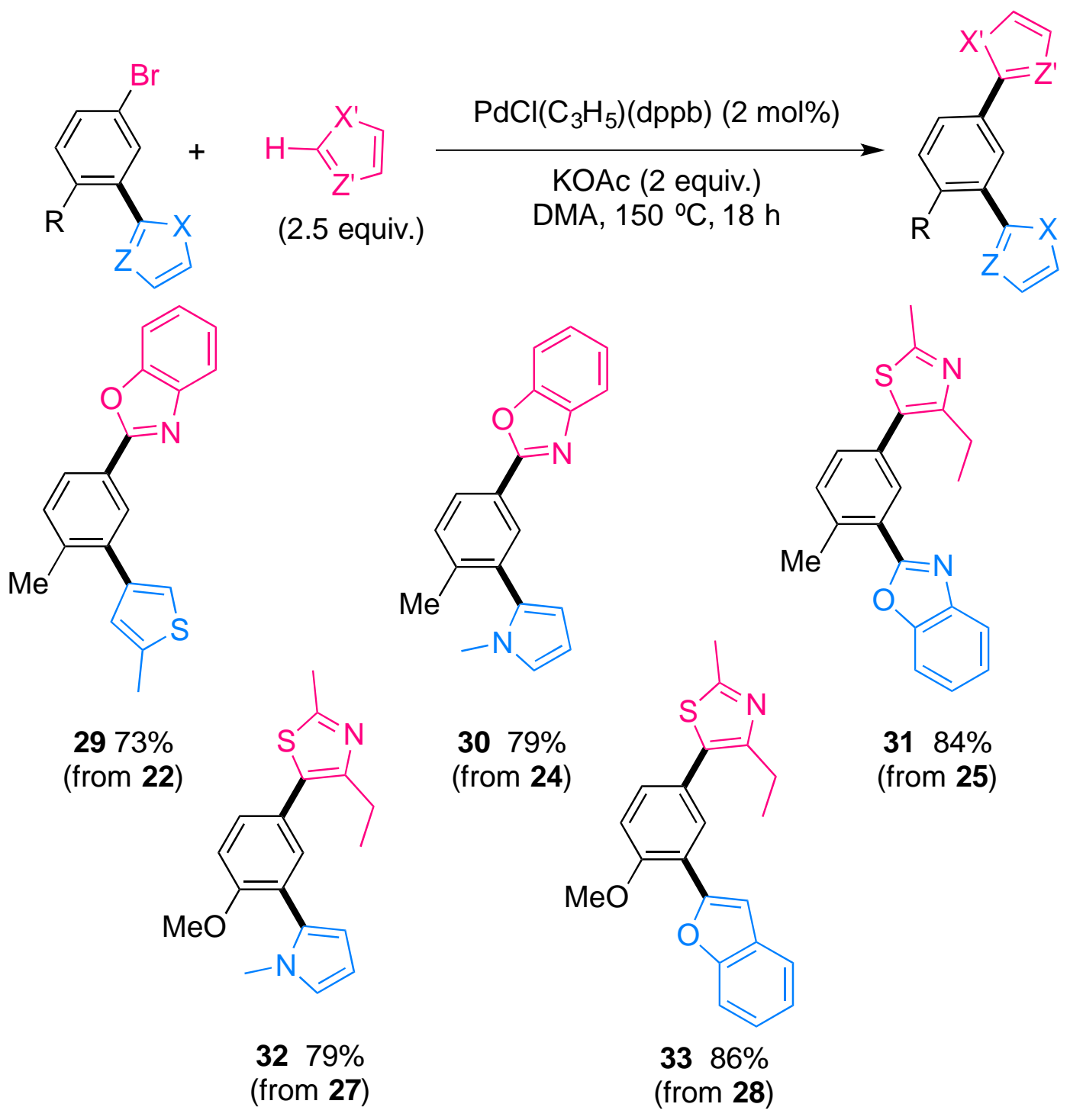

\section{Conclusion}

In summary, we have developed two new routes for the eco-friendly two steps synthesis of unsymmetrical 1,3diheteroarylbenzenes. The first strategy uses a desymmetrization of benzene-1,3-disulfonyl dichloride through two successive Pd-catalyzed desulfitative direct arylations of heteroarenes. The key to stop the reaction at the monoarylation stage lies in the use of diethyl carbonate (DEC) as solvent or to perform the reaction at a moderate reaction temperature. A wide range of heteroarenes has been used including thiophenes, with which the arylation occurred at the $\beta$-position. Then, a second desulfitative arylation with a different heteroarene delivered the desired 1,3-disubstituted benzenes. The second strategy employs the tolerance to $\mathrm{C}-\mathrm{Br}$ bonds in the desulfitative coupling to perform iterative $\mathrm{C}-\mathrm{H}$ arylations with two different heteroarenes. The combination of both strategies gives a robust access to uncommon 1,3-diheteroarylbenzenes, which could find further applications as tridentate ligands.

\section{Experimental Section}

All reactions were carried out under argon atmosphere with standard Schlenk techniques. 1,4-Dioxane, diethyl carbonate (DEC), cyclopentylmethyl ether (CPME) and DMA were purchased from Acros Organics and were not purified before use. 1,3-Benzenedisulfonyl chloride was purchased from TCI. The other benzenesulfonyl chlorides were prepared from bromobenzene by chlorosulfonylation $\left(\mathrm{HSO}_{3} \mathrm{Cl}\right)$ using a reported procedure. ${ }^{21}{ }^{1} \mathrm{H}$ NMR spectra were recorded on Bruker GPX $(400 \mathrm{MHz})$ spectrometer. Chemical shifts $(\delta)$ were reported in parts per million relative to residual chloroform $\left(7.26 \mathrm{ppm}\right.$ for ${ }^{1} \mathrm{H} ; 77.0 \mathrm{ppm}$ for $\left.{ }^{13} \mathrm{C}\right)$, constants were reported in Hertz. ${ }^{1} \mathrm{H}$ NMR assignment abbreviations were the following: singlet (s), doublet (d), triplet (t), quartet (q), doublet of doublets (dd), 
doublet of triplets (dt), and multiplet (m). ${ }^{13} \mathrm{C}$ NMR spectra were recorded at $100 \mathrm{MHz}$ on the same spectrometer and reported in ppm.

Preparation of the PdCl(dppb) $\left(\mathbf{C}_{3} \mathbf{H}_{5}\right)$ catalyst: ${ }^{22}$ An oven-dried $40-\mathrm{mL}$ Schlenk tube equipped with a magnetic stirring bar under argon atmosphere, was charged with $\left[\mathrm{Pd}\left(\mathrm{C}_{3} \mathrm{H}_{5}\right) \mathrm{Cl}\right]_{2}(182 \mathrm{mg}, 0.5 \mathrm{mmol})$ and $\mathrm{dppb}(426 \mathrm{mg}, 1$ $\mathrm{mmol}$ ). $10 \mathrm{~mL}$ of anhydrous dichloromethane were added, then the solution was stirred at room temperature for twenty minutes. The solvent was removed in vacuum. The yellow powder was used without purification. ${ }^{31} \mathrm{P}$ NMR $\left(81 \mathrm{MHz}, \mathrm{CDCl}_{3}\right) \delta(\mathrm{ppm})=19.3(\mathrm{~s})$.

Procedure A (desulfitative arylation): To a $5 \mathrm{~mL}$ oven dried Schlenk tube, arylsulfonyl chloride (1.2 or 1 mmol), heteroarenes derivatives (1-3 mmol), $\mathrm{Li}_{2} \mathrm{CO}_{3}(222 \mathrm{mg}, 3 \mathrm{mmol}$ or $444 \mathrm{mg}, 6 \mathrm{mmol})$, 1,4-dioxane or DEC (3 $\mathrm{mL}$ ) and bis(acetonitrile)dichloropalladium(II) $(12 \mathrm{mg}, 0.05 \mathrm{mmol})$ were successively added. The reaction mixture was evacuated by vacuum-argon cycles ( 5 times) and stirred at 110 or $140{ }^{\circ} \mathrm{C}$ (oil bath temperature) for $16-48$ hours (see tables and schemes). After cooling the reaction at room temperature and concentration, the crude mixture was purified by silica column chromatography to afford the desired arylated products.

Procedure B (direct arylation with aryl bromides): To a $5 \mathrm{~mL}$ oven dried Schlenk tube, heteroaryl (2.5-3 mmol), aryl bromide (1 mmol), AcOK (200 mg, $2 \mathrm{mmol})$, DMA ( $2 \mathrm{~mL})$ and $\mathrm{PdCl}\left(\mathrm{C}_{3} \mathrm{H}_{5}\right)(\mathrm{dppb})(12 \mathrm{mg}, 0.02 \mathrm{mmol}, 2$ mol\%) were successively added. The reaction mixture was evacuated by vacuum-argon cycles (5 times) and stirred at $150{ }^{\circ} \mathrm{C}$ (oil bath temperature) for 16-48 hours (see tables and schemes). After cooling the reaction at room temperature and concentration, the crude mixture was purified by silica column chromatography to afford the desired arylated products.

3-(5-Butylfuran-2-yl)benzenesulfonyl chloride (1): Following the procedure A using 2- $n$-butylfuran (124 mg, 1 $\mathrm{mmol}$ ) and benzene-1,3-disulfonyl dichloride $(330 \mathrm{mg}, 1.2 \mathrm{mmol})$, the residue was purified by flash chromatography on silica gel $\left(\mathrm{SiO}_{2}\right.$, Pentane-AcOEt 85:15) to afford the desired compound 1 (260 $\left.\mathrm{mg}, 87 \%\right)$.

${ }^{1} \mathrm{H}$ NMR $\left(400 \mathrm{MHz}, \mathrm{CDCl}_{3}\right) \delta(\mathrm{ppm}) 8.23(\mathrm{~s}, 1 \mathrm{H}), 7.92(\mathrm{~d}, J=7.9 \mathrm{~Hz}, 1 \mathrm{H}), 7.83(\mathrm{~d}, J=7.9 \mathrm{~Hz}, 1 \mathrm{H}), 7.58(\mathrm{t}, J=7.9$ $\mathrm{Hz}, 1 \mathrm{H}), 6.72(\mathrm{~d}, J=3.3 \mathrm{~Hz}, 1 \mathrm{H}), 6.13(\mathrm{~d}, J=3.3 \mathrm{~Hz}, 1 \mathrm{H}), 2.71(\mathrm{t}, J=7.1 \mathrm{~Hz}, 2 \mathrm{H}), 1.69$ (quint., $J=7.2 \mathrm{~Hz}, 2 \mathrm{H})$, 1.43 (sext., $J=7.2 \mathrm{~Hz}, 2 \mathrm{H}), 0.97$ (t, $J=7.2 \mathrm{~Hz}, 3 \mathrm{H}$ ).

${ }^{13} \mathrm{C}$ NMR $\left(75 \mathrm{MHz}, \mathrm{CDCl}_{3}\right) \delta(\mathrm{ppm}) 157.0,151.1,137.6,132.1,129.3,125.9,122.7,122.3,107.0,106.6,30.2,27.9$, 22.3, 13.8.

Elemental analysis: calcd (\%) for $\mathrm{C}_{14} \mathrm{H}_{15} \mathrm{ClO}_{3} \mathrm{~S}$ (298.78): C 56.28, H 5.06; found: C 56.35, H 5.29.

1,3-Bis(5-butylfuran-2-yl)benzene (2): Following the procedure A using 2-n-butylfuran (252 mg, $3 \mathrm{mmol})$ and benzene-1,3-disulfonyl dichloride $(275 \mathrm{mg}, 1 \mathrm{mmol})$, the residue was purified by flash chromatography on silica gel $\left(\mathrm{SiO}_{2}\right.$, Pentane-AcOEt 95:05) to afford the desired compound 2 (271 mg, 84\%).

${ }^{1} \mathrm{H} \mathrm{NMR}\left(400 \mathrm{MHz}, \mathrm{CDCl}_{3}\right) \delta(\mathrm{ppm}) 7.91(\mathrm{~s}, 1 \mathrm{H}), 7.51(\mathrm{~d}, J=7.8 \mathrm{~Hz}, 2 \mathrm{H}), 7.37(\mathrm{t}, J=7.8 \mathrm{~Hz}, 1 \mathrm{H}), 6.62(\mathrm{~d}, J=3.2$ $\mathrm{Hz}, 2 \mathrm{H}), 6.10(\mathrm{~d}, J=3.2 \mathrm{~Hz}, 2 \mathrm{H}), 2.73(\mathrm{t}, J=7.4 \mathrm{~Hz}, 4 \mathrm{H}), 1.72$ (quint, $J=7.4 \mathrm{~Hz}, 4 \mathrm{H}), 1.46(\mathrm{sext}, J=7.4 \mathrm{~Hz}, 4 \mathrm{H})$, $0.99(\mathrm{t}, J=7.4 \mathrm{~Hz}, 6 \mathrm{H})$.

${ }^{13} \mathrm{C}$ NMR $\left(75 \mathrm{MHz}, \mathrm{CDCl}_{3}\right.$ ) $\delta$ (ppm) 156.6, 152.0, 131.6, 128.8, 121.8, 118.2, 106.8, 106.0, 30.2, 27.9, 22.3, 13.8.

Elemental analysis: calcd (\%) for $\mathrm{C}_{22} \mathrm{H}_{26} \mathrm{O}_{2}$ (322.45): C 81.95, $\mathrm{H}$ 8.13; found: $\mathrm{C} 82.17, \mathrm{H}$ 8.01.

2-(3-Bromophenyl)-5-n-butylfuran (3): To a $5 \mathrm{~mL}$ oven dried Schlenk tube, 2-n-butylfuran (124 mg, $1 \mathrm{mmol})$, 1,3-dibromobenzene (1180 mg, $5 \mathrm{mmol})$, AcOK (100 mg, $1 \mathrm{mmol})$, DMA (2 mL) and Pd(OAc) $(1.1 \mathrm{mg}, 0.005$ mmol, $0.5 \mathrm{~mol} \%$ ) were successively added. The reaction mixture was evacuated by vacuum-argon cycles ( 5 times) and stirred at $150{ }^{\circ} \mathrm{C}$ (oil bath temperature) for 16hours. After cooling the reaction at room temperature and concentration, the crude mixture was purified by silica column chromatography $\left(\mathrm{SiO}_{2}\right.$, Pentane-AcOEt 90:10) to afford the desired arylated product 3 (145 $\mathrm{mg}, 52 \%)$.

${ }^{1} \mathrm{H}$ NMR $\left(400 \mathrm{MHz}, \mathrm{CDCl}_{3}\right) \delta(\mathrm{ppm}) 7.79(\mathrm{~s}, 1 \mathrm{H}), 7.56(\mathrm{~d}, J=8.2 \mathrm{~Hz}, 1 \mathrm{H}), 7.35(\mathrm{~d}, J=8.2 \mathrm{~Hz}, 1 \mathrm{H}), 7.23(\mathrm{t}, J=7.8$ $\mathrm{Hz}, 1 \mathrm{H}), 6.58(\mathrm{~d}, J=3.2 \mathrm{~Hz}, 1 \mathrm{H}), 6.09(\mathrm{~d}, J=3.2 \mathrm{~Hz}, 1 \mathrm{H}), 2.71(\mathrm{t}, J=7.4 \mathrm{~Hz}, 2 \mathrm{H}), 1.69$ (quint., $J=7.4 \mathrm{~Hz}, 2 \mathrm{H}$ ), 1.43 (sext., $J=7.4 \mathrm{~Hz}, 2 \mathrm{H}$ ), 0.98 (t, $J=7.4 \mathrm{~Hz}, 3 \mathrm{H}$ ).

This is a known compound and the spectral data are identical to those reported in literature. ${ }^{16}$

3-(5-(2-Oxopropyl)furan-2-yl)benzenesulfonyl chloride (4): Following the procedure A using 1-(furan-2yl)propan-2-one $(124 \mathrm{mg}, 1 \mathrm{mmol})$ and benzene-1,3-disulfonyl dichloride (330 $\mathrm{mg}, 1.2 \mathrm{mmol})$, the residue was purified by flash chromatography on silica gel $\left(\mathrm{SiO}_{2}\right.$, Pentane-AcOEt 85:15) to afford the desired compound 4 (227 $\mathrm{mg}, 76 \%)$.

${ }^{1} \mathrm{H}$ NMR $\left(400 \mathrm{MHz}, \mathrm{CDCl}_{3}\right) \delta(\mathrm{ppm}) 8.24(\mathrm{t}, J=1.9 \mathrm{~Hz}, 1 \mathrm{H}), 7.94(\mathrm{td}, J=1.9$ and $7.6 \mathrm{~Hz}, 1 \mathrm{H}), 7.88(\mathrm{td}, J=1.9$ and $7.6 \mathrm{~Hz}, 1 \mathrm{H}), 7.61(\mathrm{t}, J=7.9 \mathrm{~Hz}, 1 \mathrm{H}), 6.80(\mathrm{~d}, J=3.4 \mathrm{~Hz}, 1 \mathrm{H}), 6.37(\mathrm{~d}, J=3.4 \mathrm{~Hz}, 1 \mathrm{H}), 3.83(\mathrm{~s}, 2 \mathrm{H}), 2.26(\mathrm{~s}, 3 \mathrm{H})$.

${ }^{13} \mathrm{C}$ NMR $\left(75 \mathrm{MHz}, \mathrm{CDCl}_{3}\right) \delta$ (ppm) 203.1, 150.8, 149.7, 145.0, 132.4, 130.1, 129.6, 124.9, 121.6, 111.0, 108.9, 43.2, 29.5.

Elemental analysis: calcd (\%) for $\mathrm{C}_{13} \mathrm{H}_{11} \mathrm{ClO}_{4} \mathrm{~S}$ (298.74): C 52.27, H 3.71; found: C 52.49, H 4.05. 
3-(Benzofuran-2-yl)benzenesulfonyl chloride (5): Following the procedure A using benzofuran (118 mg, 1 $\mathrm{mmol}$ ) and benzene-1,3-disulfonyl dichloride (330 $\mathrm{mg}, 1.2 \mathrm{mmol})$, the residue was purified by flash chromatography on silica gel $\left(\mathrm{SiO}_{2}\right.$, Pentane-AcOEt 85:15) to afford the desired compound $5(199 \mathrm{mg}, 68 \%)$.

${ }^{1} \mathrm{H}$ NMR $\left(400 \mathrm{MHz}, \mathrm{CDCl}_{3}\right) \delta(\mathrm{ppm}) 8.50(\mathrm{~s}, 1 \mathrm{H}), 8.18(\mathrm{~d}, J=7.9 \mathrm{~Hz}, 1 \mathrm{H}), 7.99(\mathrm{~d}, J=7.9 \mathrm{~Hz}, 1 \mathrm{H}), 7.69(\mathrm{t}, J=7.9$ $\mathrm{Hz}, 1 \mathrm{H}), 7.64(\mathrm{~d}, J=7.5 \mathrm{~Hz}, 1 \mathrm{H}), 7.56(\mathrm{~d}, J=7.9 \mathrm{~Hz}, 1 \mathrm{H}), 7.37(\mathrm{dt}, J=1.4$ and $7.9 \mathrm{~Hz}, 1 \mathrm{H}), 7.28(\mathrm{t}, J=7.5 \mathrm{~Hz}, 1 \mathrm{H})$, $7.20(\mathrm{~s}, 1 \mathrm{H})$.

${ }^{13} \mathrm{C} \mathrm{NMR}\left(100 \mathrm{MHz}, \mathrm{CDCl}_{3}\right) \delta(\mathrm{ppm}) 155.2,152.7,145.2,132.5,130.9,130.3,128.6,126.1,125.6,123.6,123.0$, 121.6, 111.5, 104.1.

Elemental analysis: calcd (\%) for $\mathrm{C}_{14} \mathrm{H}_{9} \mathrm{ClO}_{3} \mathrm{~S}$ (292.73): C 57.44, H 3.10; found: C 57.69, H 3.29.

3-(1-Methylpyrrol-2-yl)benzenesulfonyl chloride (6): Following the procedure A using 1-methylpyrrole (81 mg, $1 \mathrm{mmol}$ ) and benzene-1,3-disulfonyl dichloride (330 $\mathrm{mg}, 1.2 \mathrm{mmol}$ ), the residue was purified by flash chromatography on silica gel $\left(\mathrm{SiO}_{2}\right.$, Pentane-AcOEt 90:10) to afford the desired compound 6 (189 mg, 74\%).

${ }^{1} \mathrm{H}$ NMR $\left(400 \mathrm{MHz}, \mathrm{CDCl}_{3}\right) \delta(\mathrm{ppm}) 8.08(\mathrm{~s}, 1 \mathrm{H}), 7.95(\mathrm{~d}, J=7.9 \mathrm{~Hz}, 1 \mathrm{H}), 7.79(\mathrm{~d}, J=8.9 \mathrm{~Hz}, 1 \mathrm{H}), 7.66(\mathrm{t}, J=7.9$ $\mathrm{Hz}, 1 \mathrm{H}), 6.82(\mathrm{t}, J=2.3 \mathrm{~Hz}, 1 \mathrm{H}), 6.39(\mathrm{dd}, J=1.8$ and $3.7 \mathrm{~Hz}, 1 \mathrm{H}), 6.26(\mathrm{dd}, J=2.7$ and $3.7 \mathrm{~Hz}, 1 \mathrm{H}), 3.74(\mathrm{~s}, 3 \mathrm{H})$.

${ }^{13} \mathrm{C}$ NMR $\left(100 \mathrm{MHz}, \mathrm{CDCl}_{3}\right) \delta(\mathrm{ppm}) 144.5,135.2,134.4,131.5,129.7,125.9,125.5,124.3,110.6,108.5,35.2$.

Elemental analysis: calcd (\%) for $\mathrm{C}_{11} \mathrm{H}_{10} \mathrm{ClNO}_{2} \mathrm{~S}$ (255.71): C 51.67, H 3.94; found: C 51.95, H 4.11.

3-(1-Phenylpyrrol-2-yl)benzenesulfonyl chloride (7): Following the procedure A using 1-phenylpyrrole (143 $\mathrm{mg}, 1 \mathrm{mmol})$ and benzene-1,3-disulfonyl dichloride $(330 \mathrm{mg}, 1.2 \mathrm{mmol})$, the residue was purified by flash chromatography on silica gel $\left(\mathrm{SiO}_{2}\right.$, Pentane-AcOEt 80:20) to afford the desired compound 7 (219 $\left.\mathrm{mg}, 69 \%\right)$.

${ }^{1} \mathrm{H}$ NMR $\left(400 \mathrm{MHz}, \mathrm{CDCl}_{3}\right) \delta(\mathrm{ppm}) 7.78(\mathrm{~d}, J=7.7 \mathrm{~Hz}, 1 \mathrm{H}), 7.73(\mathrm{~s}, 1 \mathrm{H}), 7.49-7.33(\mathrm{~m}, 5 \mathrm{H}), 7.18(\mathrm{~d}, J=8.3 \mathrm{~Hz}$, 2H), $7.02(\mathrm{dd}, J=1.7$ and $2.8 \mathrm{~Hz}, 1 \mathrm{H}), 6.61(\mathrm{dd}, J=1.7$ and $3.7 \mathrm{~Hz}, 1 \mathrm{H}), 6.42(\mathrm{dd}, J=2.8,3.7 \mathrm{~Hz}, 1 \mathrm{H})$.

${ }^{13} \mathrm{C}$ NMR $\left(100 \mathrm{MHz}, \mathrm{CDCl}_{3}\right) \delta(\mathrm{ppm}) 144.2,139.6,134.8,134.0,130.8,129.5,129.3,127.5,126.1,125.8,125.8$, $123.8,112.3,109.8$.

Elemental analysis: calcd (\%) for $\mathrm{C}_{16} \mathrm{H}_{12} \mathrm{ClNO}_{2} \mathrm{~S}$ (317.79): C 60.47, H 3.81; found: C 60.58, H 3.96.

3-(5-Methylthiophen-3-yl)benzenesulfonyl chloride (8): Following the procedure A using 2-methylthiophene (98 $\mathrm{mg}, 1 \mathrm{mmol})$ and benzene-1,3-disulfonyl dichloride $(330 \mathrm{mg}, 1.2 \mathrm{mmol})$, the residue was purified by flash chromatography on silica gel ( $\mathrm{SiO}_{2}$, Pentane-AcOEt 85:15) to afford the desired compound 8 (158 mg, 58\%).

${ }^{1} \mathrm{H} \mathrm{NMR}\left(400 \mathrm{MHz}, \mathrm{CDCl}_{3}\right) \delta(\mathrm{ppm}) 8.17(\mathrm{~s}, 1 \mathrm{H}), 7.90-7.85(\mathrm{~m}, 2 \mathrm{H}), 7.59$ (t, $\left.J=7.9 \mathrm{~Hz}, 1 \mathrm{H}\right), 7.34$ (s, $\left.1 \mathrm{H}\right), 7.09$ (s, $1 \mathrm{H}), 2.54(\mathrm{~s}, 3 \mathrm{H})$.

${ }^{13} \mathrm{C}$ NMR $\left(100 \mathrm{MHz}, \mathrm{CDCl}_{3}\right) \delta(\mathrm{ppm}) 144.9,141.9,139.1,138.0,132.6,130.1,124.9,124.3,124.1,120.3,14.4$.

Elemental analysis: calcd (\%) for $\mathrm{C}_{11} \mathrm{H}_{9} \mathrm{ClO}_{2} \mathrm{~S}_{2}$ (272.76): C 48.44, H 3.33; found: C 48.67, H 3.58.

3-(5-Bromothiophen-3-yl)benzenesulfonyl chloride (9): Following the procedure A using 2-bromothiophene (163 $\mathrm{mg}, 1 \mathrm{mmol})$ and benzene-1,3-disulfonyl dichloride $(330 \mathrm{mg}, 1.2 \mathrm{mmol})$, the residue was purified by flash chromatography on silica gel $\left(\mathrm{SiO}_{2}\right.$, Pentane-AcOEt 80:20) to afford the desired compound 9 (159 mg, 47\%).

${ }^{1} \mathrm{H}$ NMR $\left(400 \mathrm{MHz}, \mathrm{CDCl}_{3}\right) \delta(\mathrm{ppm}) 8.15(\mathrm{~s}, 1 \mathrm{H}), 7.96(\mathrm{~d}, J=8.0 \mathrm{~Hz}, 1 \mathrm{H}), 7.87(\mathrm{~d}, J=8.0 \mathrm{~Hz}, 1 \mathrm{H}), 7.65(\mathrm{t}, J=8.0$ $\mathrm{Hz}, 1 \mathrm{H}), 7.48(\mathrm{~s}, 1 \mathrm{H}), 7.38(\mathrm{~s}, 1 \mathrm{H})$.

${ }^{13} \mathrm{C} \mathrm{NMR}\left(100 \mathrm{MHz}, \mathrm{CDCl}_{3}\right) \delta(\mathrm{ppm}) 145.0,139.8,136.7,132.5,130.3,128.6,125.5,124.3,123.6,114.3$.

Elemental analysis: calcd (\%) for $\mathrm{C}_{10} \mathrm{H}_{6} \mathrm{BrClO}_{2} \mathrm{~S}_{2}$ (337.63): C 35.57, H 1.79; found: C 35.95, H 2.23.

3-(Benzothiophen-3-yl)benzenesulfonyl chloride (10): Following the procedure A using benzothiophene (134 $\mathrm{mg}, 1 \mathrm{mmol}$ ) and benzene-1,3-disulfonyl dichloride $(330 \mathrm{mg}, 1.2 \mathrm{mmol})$, the residue was purified by flash chromatography on silica gel $\left(\mathrm{SiO}_{2}\right.$, Pentane-AcOEt 75:25) to afford the desired compound 10 (195 $\left.\mathrm{mg}, 63 \%\right)$.

${ }^{1} \mathrm{H}$ NMR $\left(400 \mathrm{MHz}, \mathrm{CDCl}_{3}\right) \delta(\mathrm{ppm}) 8.27(\mathrm{~s}, 1 \mathrm{H}), 8.08(\mathrm{~d}, J=8.0 \mathrm{~Hz}, 1 \mathrm{H}), 7.98-7.94(\mathrm{~m}, 2 \mathrm{H}), 7.86-7.81(\mathrm{~m}, 1 \mathrm{H})$, $7.75(\mathrm{t}, J=7.9 \mathrm{~Hz}, 1 \mathrm{H}), 7.56(\mathrm{~s}, 1 \mathrm{H}), 7.48-7.33(\mathrm{~m}, 2 \mathrm{H})$.

${ }^{13} \mathrm{C}$ NMR $\left(100 \mathrm{MHz}, \mathrm{CDCl}_{3}\right) \delta(\mathrm{ppm}) 145.0,145.0,140.7,138.0,137.0,135.2,135.1,130.1,126.8,125.7,125.6$, 125.0, 123.2, 122.1.

Elemental analysis: calcd (\%) for $\mathrm{C}_{14} \mathrm{H}_{9} \mathrm{ClO}_{2} \mathrm{~S}_{2}$ (308.79): C 54.46, H 2.94; found: C 54.18, H 3.13.

2-(3-(5-Butylfuran-2-yl)phenyl)-1-methylpyrrole (11): Following the procedure A using 3-(5-butylfuran-2yl)benzenesulfonyl chloride (1) $(299 \mathrm{mg}, 1 \mathrm{mmol})$ and 1-methylpyrrole (203 $\mathrm{mg}, 2.5 \mathrm{mmol})$, the residue was purified by flash chromatography on silica gel $\left(\mathrm{SiO}_{2}\right.$, Pentane-AcOEt 80:20) to afford the desired compound $11(229 \mathrm{mg}$, $82 \%)$.

${ }^{1} \mathrm{H}$ NMR $\left(400 \mathrm{MHz}, \mathrm{CDCl}_{3}\right) \delta(\mathrm{ppm}) 7.73(\mathrm{~s}, 1 \mathrm{H}), 7.61(\mathrm{~d}, J=7.8 \mathrm{~Hz}, 1 \mathrm{H}), 7.42(\mathrm{t}, J=7.8 \mathrm{~Hz}, 1 \mathrm{H}), 7.29(\mathrm{~d}, J=7.8$ $\mathrm{Hz}, 1 \mathrm{H}), 6.77(\mathrm{t}, J=2.1 \mathrm{~Hz}, 1 \mathrm{H}), 6.61(\mathrm{~d}, J=3.1 \mathrm{~Hz}, 1 \mathrm{H}), 6.32(\mathrm{dd}, J=2.0$ and $3.4 \mathrm{~Hz}, 1 \mathrm{H}), 6.27(\mathrm{t}, J=3.1 \mathrm{~Hz}, 1 \mathrm{H})$, $6.11(\mathrm{~d}, J=3.1 \mathrm{~Hz}, 1 \mathrm{H}), 3.72(\mathrm{~s}, 3 \mathrm{H}), 2.73(\mathrm{t}, J=7.6 \mathrm{~Hz}, 2 \mathrm{H}), 1.73$ (quint., $J=7.6 \mathrm{~Hz}, 2 \mathrm{H}), 1.46$ (sext., $J=7.2 \mathrm{~Hz}$, $2 \mathrm{H}), 1.00(\mathrm{t}, J=7.2 \mathrm{~Hz}, 3 \mathrm{H})$. 
${ }^{13} \mathrm{C}$ NMR $\left(100 \mathrm{MHz}, \mathrm{CDCl}_{3}\right) \delta(\mathrm{ppm}) 156.6,151.8,134.4,133.6,131.3,128.5,127.0,123.7,123.6,121.7,108.7$, $107.7,106.9,105.9,35.0,30.2,27.9,22.3,13.8$.

Elemental analysis: calcd (\%) for $\mathrm{C}_{19} \mathrm{H}_{21} \mathrm{NO}$ (279.38): C 81.68, H 7.58; found: C 81.51, H 7.76.

2-(3-(Benzofuran-2-yl)phenyl)-1-methylpyrrole (12): Following the procedure A using 3-(benzofuran-2yl)benzenesulfonyl chloride (5) $(293 \mathrm{mg}, 1 \mathrm{mmol})$ and 1-methylpyrrole (203 mg, $2.5 \mathrm{mmol})$, the residue was purified by flash chromatography on silica gel $\left(\mathrm{SiO}_{2}\right.$, Pentane-AcOEt 70:30) to afford the desired compound $12(200 \mathrm{mg}$, $73 \%)$.

${ }^{1} \mathrm{H}$ NMR $\left(400 \mathrm{MHz}, \mathrm{CDCl}_{3}\right) \delta(\mathrm{ppm}) 7.95(\mathrm{~s}, 1 \mathrm{H}), 7.82(\mathrm{~d}, J=8.0 \mathrm{~Hz}, 1 \mathrm{H}), 7.62(\mathrm{~d}, J=7.4 \mathrm{~Hz}, 1 \mathrm{H}), 7.56(\mathrm{~d}, J=8.0$ $\mathrm{Hz}, 1 \mathrm{H}), 7.50(\mathrm{t}, J=7.6 \mathrm{~Hz}, 1 \mathrm{H}), 7.42(\mathrm{~d}, J=7.6 \mathrm{~Hz}, 1 \mathrm{H}), 7.32(\mathrm{t}, J=7.5 \mathrm{~Hz}, 1 \mathrm{H}), 7.29-7.24(\mathrm{~m}, 1 \mathrm{H}), 7.07(\mathrm{~s}, 1 \mathrm{H})$, 6.79 (dd, $J=1.8$ and $2.8 \mathrm{~Hz}, 1 \mathrm{H}), 6.36(\mathrm{td}, J=1.83$ and $3.7 \mathrm{~Hz}, 1 \mathrm{H}), 6.29-6.27(\mathrm{~m}, 1 \mathrm{H}), 3.74(\mathrm{~s}, 3 \mathrm{H})$.

${ }^{13} \mathrm{C}$ NMR $\left(100 \mathrm{MHz}, \mathrm{CDCl}_{3}\right) \delta(\mathrm{ppm}) 155.7,154.9,134.0,133.9,130.6,129.1,128.8,128.7,125.1,124.3,123.9$, $123.2,122.9,120.9,111.2,109.0,107.9,101.6,35.1$.

Elemental analysis: calcd (\%) for $\mathrm{C}_{19} \mathrm{H}_{15} \mathrm{NO}$ (273.34): C 83.49, H 5.53; found: C 83.21, H 5.19.

2-(3-(1-Methylpyrrol-2-yl)phenyl)benzoxazole (13): Following the procedure A using 3-(1-methylpyrrol-2yl)benzenesulfonyl chloride (6) $(256 \mathrm{mg}, 1 \mathrm{mmol})$, benzoxazole $(298 \mathrm{mg}, 2.5 \mathrm{mmol})$ and $\mathrm{CuI}(190 \mathrm{mg}, 1 \mathrm{mmol})$, the residue was purified by flash chromatography on silica gel $\left(\mathrm{SiO}_{2}\right.$, Pentane-AcOEt 70:30) to afford the desired compound $13(187 \mathrm{mg}, 68 \%)$.

${ }^{1} \mathrm{H}$ NMR $\left(400 \mathrm{MHz}, \mathrm{CDCl}_{3}\right) \delta(\mathrm{ppm}) 8.32(\mathrm{~s}, 1 \mathrm{H}), 8.20(\mathrm{td}, J=1.9$ and $7.0 \mathrm{~Hz}, 1 \mathrm{H}), 7.80(\mathrm{dd}, J=3.1$ and $6.0 \mathrm{~Hz}$, $1 \mathrm{H}), 7.62-7.63(\mathrm{~m}, 3 \mathrm{H}), 7.37(\mathrm{dd}, J=3.2$ and $6.0 \mathrm{~Hz}, 2 \mathrm{H}), 6.77(\mathrm{dd}, J=1.8$ and $2.7 \mathrm{~Hz}, 1 \mathrm{H}), 6.37(\mathrm{dd}, J=1.8$ and $3.7 \mathrm{~Hz}, 1 \mathrm{H}), 6.25(\mathrm{dd}, J=2.7$ and $3.6 \mathrm{~Hz}, 1 \mathrm{H}), 3.75(\mathrm{~s}, 3 \mathrm{H})$.

${ }^{13} \mathrm{C}$ NMR $\left(100 \mathrm{MHz}, \mathrm{CDCl}_{3}\right) \delta(\mathrm{ppm}) 162.8,150.7,142.1,134.2,133.4,131.4,129.0,127.4,127.3,125.7,125.1$, 124.6, 124.3, 120.0, 110.6, 109.4, 108.0, 35.2.

Elemental analysis: calcd (\%) for $\mathrm{C}_{18} \mathrm{H}_{14} \mathrm{~N}_{2} \mathrm{O}$ (274.32): C 78.81, H 5.14; found: C 79.06, H 4.87.

2-(3-(1-Phenylpyrrol-2-yl)phenyl)benzoxazole (14): Following the procedure A using 3-(1-phenylpyrrol-2yl)benzenesulfonyl chloride (7) $(318 \mathrm{mg}, 1 \mathrm{mmol})$, benzoxazole $(298 \mathrm{mg}, 2.5 \mathrm{mmol})$ and $\mathrm{CuI}(190 \mathrm{mg}, 1 \mathrm{mmol})$, the residue was purified by flash chromatography $\left(\mathrm{SiO}_{2}\right.$, Pentane-AcOEt 70:30) on silica gel to afford the desired compound $14(212 \mathrm{mg}, 63 \%)$.

${ }^{1} \mathrm{H}$ NMR $\left(400 \mathrm{MHz}, \mathrm{CDCl}_{3}\right) \delta(\mathrm{ppm}) 8.22(\mathrm{~s}, 1 \mathrm{H}), 8.07(\mathrm{~d}, J=7.7 \mathrm{~Hz}, 1 \mathrm{H}), 7.78(\mathrm{dd}, J=3.0$ and $6.3 \mathrm{~Hz}, 1 \mathrm{H}), 7.38-$ $7.32(\mathrm{~m}, 5 \mathrm{H}), 7.30(\mathrm{~d}, J=7.4 \mathrm{~Hz}, 2 \mathrm{H}), 7.23(\mathrm{~d}, J=7.4 \mathrm{~Hz}, 2 \mathrm{H}), 7.14(\mathrm{~d}, J=6.4 \mathrm{~Hz}, 1 \mathrm{H}), 7.01(\mathrm{t}, J=2.2 \mathrm{~Hz}, 1 \mathrm{H})$, $6.61(\mathrm{dd}, J=1.8$ and $3.6 \mathrm{~Hz}, 1 \mathrm{H}), 6.42(\mathrm{t}, J=3.2 \mathrm{~Hz}, 1 \mathrm{H})$.

${ }^{13} \mathrm{C}$ NMR $\left(100 \mathrm{MHz}, \mathrm{CDCl}_{3}\right) \delta(\mathrm{ppm}) 162.9,150.7,142.1,140.3,133.8,132.6,131.2,129.1,128.5,127.2,126.8$, $125.8,125.4,125.1,124.9,124.5,120.0,111.4,110.5,109.4$.

Elemental analysis: calcd (\%) for $\mathrm{C}_{23} \mathrm{H}_{16} \mathrm{~N}_{2} \mathrm{O}$ (336.39): C 82.12, H 4.79; found: C 82.17, H 5.01.

1-Methyl-2-(3-(1-phenylpyrrol-2-yl)phenyl)pyrrole (15): Following the procedure A using 3-(1-phenylpyrrol-2yl)benzenesulfonyl chloride (7) $(318 \mathrm{mg}, 1 \mathrm{mmol})$ and 1-methylpyrrole $(203 \mathrm{mg}, 2.5 \mathrm{mmol})$, the residue was purified by flash chromatography on silica gel $\left(\mathrm{SiO}_{2}\right.$, Pentane-AcOEt 75:25) to afford the desired compound 15 (245 mg, $82 \%)$.

${ }^{1} \mathrm{H}$ NMR $\left(400 \mathrm{MHz}, \mathrm{CDCl}_{3}\right) \delta(\mathrm{ppm})$ 7.44-7.38 (m, 2H), 7.37-7.32 (m, 2H), 7.31-7.26 (m, 4H), 7.17 (s, 1H), 7.02 (t, $J=2.4 \mathrm{~Hz}, 1 \mathrm{H}), 6.69(\mathrm{t}, J=2.3 \mathrm{~Hz}, 1 \mathrm{H}), 6.56(\mathrm{dd}, J=1.8$ and $3.6 \mathrm{~Hz}, 1 \mathrm{H}), 6.46(\mathrm{dd}, J=2.7$ and $3.6 \mathrm{~Hz}, 1 \mathrm{H}), 6.21$ (dd, $J=2.7$ and $3.6 \mathrm{~Hz}, 1 \mathrm{H}), 6.13(\mathrm{dd}, J=1.8$ and $3.6 \mathrm{~Hz}, 1 \mathrm{H}), 3.39(\mathrm{~s}, 3 \mathrm{H})$.

${ }^{13} \mathrm{C}$ NMR $\left(100 \mathrm{MHz}, \mathrm{CDCl}_{3}\right) \delta(\mathrm{ppm}) 140.6,134.2,133.5,132.9,129.1,128.4,128.3,126.5,126.5,126.4,125.8$, $124.5,123.5,110.9,109.3,108.6,107.6,34.6$.

Elemental analysis: calcd (\%) for $\mathrm{C}_{21} \mathrm{H}_{18} \mathrm{~N}_{2}$ (298.39): C 84.53, H 6.08; found: C 84.72, H 5.98.

1-Methyl-2-(3-(5-methylthiophen-3-yl)phenyl)pyrrole (16): Following the procedure A using 3-(5methylthiophen-3-yl)benzenesulfonyl chloride (8) $(273 \mathrm{mg}, 1 \mathrm{mmol})$ and 1-methylpyrrole $(203 \mathrm{mg}$, $2.5 \mathrm{mmol})$, the residue was purified by flash chromatography on silica gel $\left(\mathrm{SiO}_{2}\right.$, Pentane-AcOEt $\left.85: 15\right)$ to afford the desired compound 16 (205 $\mathrm{mg}, 81 \%)$.

${ }^{1} \mathrm{H}$ NMR $\left(400 \mathrm{MHz}, \mathrm{CDCl}_{3}\right) \delta(\mathrm{ppm}) 7.62(\mathrm{~s}, 1 \mathrm{H}), 7.50(\mathrm{~d}, J=7.5 \mathrm{~Hz}, 1 \mathrm{H}), 7.41(\mathrm{t}, J=7.6 \mathrm{~Hz}, 1 \mathrm{H}), 7.32(\mathrm{~d}, J=7.6$ $\mathrm{Hz}, 1 \mathrm{H}), 7.22(\mathrm{~s}, 1 \mathrm{H}), 7.09(\mathrm{~s}, 1 \mathrm{H}), 6.74(\mathrm{t}, J=2.3 \mathrm{~Hz}, 1 \mathrm{H}), 6.29(\mathrm{dd}, J=1.7$ and $3.1 \mathrm{~Hz}, 1 \mathrm{H}), 6.24(\mathrm{t}, J=2.8 \mathrm{~Hz}$, $1 \mathrm{H}), 3.69(\mathrm{~s}, 3 \mathrm{H}), 2.54(\mathrm{~s}, 3 \mathrm{H})$.

${ }^{13} \mathrm{C}$ NMR $\left(75 \mathrm{MHz}, \mathrm{CDCl}_{3}\right) \delta(\mathrm{ppm}) 141.7,140.5,136.2,134.4,133.7,128.6,127.1,126.6,124.6,124.5,123.6$, 118.2, 108.7, 107.8, 35.0, 15.4.

Elemental analysis: calcd (\%) for $\mathrm{C}_{16} \mathrm{H}_{15} \mathrm{NS}$ (253.36): C 75.85, H 5.97; found: C 76.03, H 5.78.

1,3-Bis(5-methylthiophen-3-yl)benzene (17): Following the procedure A using 2-methylthiophene (294 $\mathrm{mg}, 3$ $\mathrm{mmol}$ ) and benzene-1,3-disulfonyl dichloride $(275 \mathrm{mg}, 1 \mathrm{mmol})$, the residue was purified by flash chromatography on silica gel $\left(\mathrm{SiO}_{2}\right.$, Pentane-AcOEt 70:30) to afford the desired compound 17 (176 mg, 65\%). 
${ }^{1} \mathrm{H}$ NMR $\left(400 \mathrm{MHz}, \mathrm{CDCl}_{3}\right) \delta(\mathrm{ppm}) 7.73(\mathrm{~s}, 1 \mathrm{H}), 7.48-7.44(\mathrm{~m}, 2 \mathrm{H}), 7.38(\mathrm{t}, J=7.9 \mathrm{~Hz}, 1 \mathrm{H}), 7.22(\mathrm{~s}, 2 \mathrm{H}), 7.0 .9$ $(\mathrm{s}, 2 \mathrm{H}), 2.54(\mathrm{~s}, 6 \mathrm{H})$.

${ }^{13} \mathrm{C}$ NMR $\left(100 \mathrm{MHz}, \mathrm{CDCl}_{3}\right) \delta$ (ppm) 142.0, 140.5, 136.6, 129.1, 124.9, 124.7, 124.3, 118.2, 15.4 .

Elemental analysis: calcd (\%) for $\mathrm{C}_{16} \mathrm{H}_{14} \mathrm{~S}_{2}$ (270.40): C 71.07, $\mathrm{H}$ 5.22; found: C 71.25, H 4.98.

1,3-Bis(1-methylpyrrol-2-yl)benzene (18): Following the procedure A using 1-methylpyrrole (405 $\mathrm{mg}, 5 \mathrm{mmol})$ and benzene-1,3-disulfonyl dichloride $(275 \mathrm{mg}, 1 \mathrm{mmol})$, the residue was purified by flash chromatography on silica gel $\left(\mathrm{SiO}_{2}\right.$, Pentane-AcOEt 80:20) to afford the desired compound 18 (201 $\left.\mathrm{mg}, 85 \%\right)$.

${ }^{1} \mathrm{H}$ NMR $\left(400 \mathrm{MHz}, \mathrm{CDCl}_{3}\right) \delta(\mathrm{ppm})$ 7.52-7.51 (m, 1H), 7.49-7.46 (m, 2H), 7.41-7.39 (m, 1H), 6.80-6.79 (m, 2H), 6.34-6.33 (m, 2H), 6.29-6.28 (m, 2H), 3.76 (s, 6H).

This is a known compound and the spectral data are identical to those reported in literature. ${ }^{23}$

1,3-Bis(1-benzylpyrrol-2-yl)benzene (19): Following the procedure A using 1-benzylpyrrole (786 $\mathrm{mg}, 5 \mathrm{mmol}$ ) and benzene-1,3-disulfonyl dichloride $(275 \mathrm{mg}, 1 \mathrm{mmol})$, the residue was purified by flash chromatography on silica gel $\left(\mathrm{SiO}_{2}\right.$, Pentane-AcOEt 85:15) to afford the desired compound 19 (307 mg, 79\%).

${ }^{1} \mathrm{H} \mathrm{NMR}\left(400 \mathrm{MHz}, \mathrm{CDCl}_{3}\right) \delta(\mathrm{ppm}) 7.34(\mathrm{~s}, 1 \mathrm{H}), 7.29-7.27(\mathrm{~m}, 2 \mathrm{H}), 7.25-7.20(\mathrm{~m}, 7 \mathrm{H}), 6.95(\mathrm{dd}, J=1.7$ and 7.5 $\mathrm{Hz}, 4 \mathrm{H}), 6.72(\mathrm{dd}, J=1.9$ and $2.8 \mathrm{~Hz}, 2 \mathrm{H}), 6.25(\mathrm{t}, J=3.0 \mathrm{~Hz}, 2 \mathrm{H}), 6.23-6.21(\mathrm{~m}, 2 \mathrm{H}), 5.08(\mathrm{~s}, 4 \mathrm{H})$.

${ }^{13} \mathrm{C}$ NMR $\left(100 \mathrm{MHz}, \mathrm{CDCl}_{3}\right) \delta(\mathrm{ppm}) 138.7,134.6,133.4,129.2,128.6,128.4,127.3,127.3,126.5,123.0,109.1$, $108.5,50.7$.

Elemental analysis: calcd (\%) for $\mathrm{C}_{28} \mathrm{H}_{24} \mathrm{~N}_{2}$ (388.51): C 86.56, H 6.23; found: C 86.79, H 6.31.

1,1'-(1,3-Phenylenebis(furan-5,2-diyl))bis(propan-2-one) (20): Following the procedure A using 1-(furan-2yl)propan-2-one (372 mg, $3 \mathrm{mmol}$ ) and benzene-1,3-disulfonyl dichloride $(275 \mathrm{mg}, 1 \mathrm{mmol})$, the residue was purified by flash chromatography on silica gel $\left(\mathrm{SiO}_{2}\right.$, Pentane-AcOEt 85:15) to afford the desired compound 20 (268 $\mathrm{mg}$, $83 \%)$.

${ }^{1} \mathrm{H}$ NMR $\left(400 \mathrm{MHz}, \mathrm{CDCl}_{3}\right) \delta(\mathrm{ppm}) 7.89(\mathrm{~s}, 1 \mathrm{H}), 7.51(\mathrm{dd}, J=1.7$ and $7.7 \mathrm{~Hz}, 2 \mathrm{H}), 7.37(\mathrm{t}, J=77.7 \mathrm{~Hz}, 1 \mathrm{H}), 6.67$ (d, $J=3.3 \mathrm{~Hz}, 2 \mathrm{H}), 6.31$ (d, $J=3.3 \mathrm{~Hz}, 2 \mathrm{H}), 3.80(\mathrm{~s}, 4 \mathrm{H}), 2.23$ (s, 6H).

${ }^{13} \mathrm{C}$ NMR $\left(100 \mathrm{MHz}, \mathrm{CDCl}_{3}\right) \delta$ (ppm) 204.0, 153.3, 148.1, 131.1, 129.0, 122.5, 118.6, 110.5, 106.5, 43.5, 29.2.

Elemental analysis: calcd (\%) for $\mathrm{C}_{20} \mathrm{H}_{18} \mathrm{O}_{4}$ (322.36): C 74.52, $\mathrm{H}$ 5.63; found: C 74.89, H 5.37.

2-(3-(Benzofuran-2-yl)phenyl)benzofuran (21): Following the procedure A using benzofuran (354 $\mathrm{mg}, 3 \mathrm{mmol}$ ) and benzene-1,3-disulfonyl dichloride $(275 \mathrm{mg}, 1 \mathrm{mmol})$, the residue was purified by flash chromatography on silica gel $\left(\mathrm{SiO}_{2}\right.$, Pentane-AcOEt 90:10) to afford the desired compound 21 (233 mg, 75\%).

${ }^{1} \mathrm{H} \mathrm{NMR}\left(400 \mathrm{MHz}, \mathrm{CDCl}_{3}\right) \delta(\mathrm{ppm}) \delta 8.38(\mathrm{~s}, 1 \mathrm{H}), 7.84(\mathrm{~d}, J=7.6 \mathrm{~Hz}, 2 \mathrm{H}), 7.63-7.52(\mathrm{~m}, 6 \mathrm{H}), 7.34-7.28(\mathrm{~m}, 3 \mathrm{H})$, $7.20(\mathrm{~s}, 2 \mathrm{H})$.

This is a known compound and the spectral data are identical to those reported in literature. ${ }^{24}$

4-(5-Bromo-2-methylphenyl)-2-methylthiophene (22): Following the procedure A using 2-methylthiophene (245 mg, $2.5 \mathrm{mmol}$ ) and 5-bromo-2-methylbenzenesulfonyl chloride $(270 \mathrm{mg}, 1 \mathrm{mmol})$, the residue was purified by flash chromatography on silica gel $\left(\mathrm{SiO}_{2}\right.$, Pentane-AcOEt 80:20) to afford the desired compound 22 (126 mg, 47\%).

${ }^{1} \mathrm{H}$ NMR $\left(400 \mathrm{MHz}, \mathrm{CDCl}_{3}\right) \delta(\mathrm{ppm}) 7.46(\mathrm{~s}, 1 \mathrm{H}), 7.35(\mathrm{~d}, J=8.2 \mathrm{~Hz}, 1 \mathrm{H}), 7.12(\mathrm{~d}, J=8.2 \mathrm{~Hz}, 1 \mathrm{H}), 6.97(\mathrm{~s}, 1 \mathrm{H})$, $6.81(\mathrm{~s}, 1 \mathrm{H}), 2.55(\mathrm{~s}, 3 \mathrm{H}), 2.31(\mathrm{~s}, 3 \mathrm{H})$.

${ }^{13} \mathrm{C}$ NMR $\left(75 \mathrm{MHz}, \mathrm{CDCl}_{3}\right) \delta(\mathrm{ppm}) 140.5,139.5,138.8,134.5,132.2,131.9,129.9,126.8,120.9,119.1,20.3,15.3$.

Elemental analysis: calcd (\%) for $\mathrm{C}_{12} \mathrm{H}_{11} \mathrm{BrS}$ (267.18): C 53.94, H 4.15; found: C 54.13, H 4.29.

2-bromo-4-(5-bromo-2-methylphenyl)thiophene (23): Following the procedure A using 2-bromothiophene (408 $\mathrm{mg}, 2.5 \mathrm{mmol})$ and 5-bromo-2-methylbenzenesulfonyl chloride $(270 \mathrm{mg}, 1 \mathrm{mmol})$, the residue was purified by flash chromatography on silica gel $\left(\mathrm{SiO}_{2}\right.$, Pentane-AcOEt 80:20) to afford the desired compound 23 (173 $\left.\mathrm{mg}, 52 \%\right)$.

${ }^{1} \mathrm{H}$ NMR $\left(400 \mathrm{MHz}, \mathrm{CDCl}_{3}\right) \delta(\mathrm{ppm}) 7.40(\mathrm{~d}, J=2.3 \mathrm{~Hz}, 1 \mathrm{H}), 7.36(\mathrm{dd}, J=2.1$ and $8.1 \mathrm{~Hz}, 1 \mathrm{H}), 7.13-7.07(\mathrm{~m}, 3 \mathrm{H})$, $2.27(\mathrm{~s}, 3 \mathrm{H})$.

${ }^{13} \mathrm{C}$ NMR $\left(75 \mathrm{MHz}, \mathrm{CDCl}_{3}\right) \delta$ (ppm) 141.3, 137.5, 134.6, 132.1, 132.1, 131.1, 130.6, 124.4, 119.3, 112.3, 20.1.

Elemental analysis: calcd (\%) for $\mathrm{C}_{11} \mathrm{H}_{8} \mathrm{Br}_{2} \mathrm{~S}$ (332.05): C 39.79, H 2.43; found: C 39.56, H 2.57.

2-(5-Bromo-2-methylphenyl)-1-methylpyrrole (24): Following the procedure A using 1-methylpyrrole (203 mg, $2.5 \mathrm{mmol})$ and 5-bromo-2-methylbenzenesulfonyl chloride $(270 \mathrm{mg}, 1 \mathrm{mmol})$, the residue was purified by flash chromatography on silica gel $\left(\mathrm{SiO}_{2}\right.$, Pentane-AcOEt 80:20) to afford the desired compound 24 (128 mg, 51\%).

${ }^{1} \mathrm{H}$ NMR $\left(400 \mathrm{MHz}, \mathrm{CDCl}_{3}\right) \delta(\mathrm{ppm}) 7.40-7.37(\mathrm{~m}, 2 \mathrm{H}), 7.13(\mathrm{~d}, J=8.8 \mathrm{~Hz}, 1 \mathrm{H}), 6.70(\mathrm{dd}, J=1.9$ and $2.7 \mathrm{~Hz}, 1 \mathrm{H})$, $6.2(\mathrm{t}, J=3.2 \mathrm{~Hz}, 1 \mathrm{H}), 6.06(\mathrm{dd}, J=1.9$ and $3.6 \mathrm{~Hz}, 1 \mathrm{H}), 3.41(\mathrm{~s}, 3 \mathrm{H}), 2.14(\mathrm{~s}, 3 \mathrm{H})$.

${ }^{13} \mathrm{C}$ NMR (100 MHz, $\left.\mathrm{CDCl}_{3}\right) \delta$ (ppm) 137.2, 135.2, 133.8, 131.7, 131.5, 130.8, 122.1, 118.8, 108.9, 107.5, 34.1, 19.6.

Elemental analysis: calcd (\%) for $\mathrm{C}_{12} \mathrm{H}_{12} \mathrm{BrN}$ (250.14): C 57.62, H 4.84; found: C 57.94, H 5.13. 
2-(5-Bromo-2-methylphenyl)benzoxazole (25): Following the procedure A using benzoxazole (298 $\mathrm{mg}, 2.5$ $\mathrm{mmol})$ and $\mathrm{CuI}(190 \mathrm{mg}, 1 \mathrm{mmol})$, 5-bromo-2-methylbenzenesulfonyl chloride (270 $\mathrm{mg}, 1 \mathrm{mmol})$, the residue was purified by flash chromatography on silica gel $\left(\mathrm{SiO}_{2}\right.$, Pentane-AcOEt 85:15) to afford the desired compound 25 (130 $\mathrm{mg}, 45 \%)$.

${ }^{1} \mathrm{H}$ NMR $\left(300 \mathrm{MHz}, \mathrm{CDCl}_{3}\right) \delta(\mathrm{ppm}) 8.34(\mathrm{~s}, 1 \mathrm{H}), 7.83-7.79(\mathrm{~m}, 1 \mathrm{H}), 7.53-7.57(\mathrm{~m}, 1 \mathrm{H}), 7.51(\mathrm{dd}, J=2.2$ and 8.2 $\mathrm{Hz}, 1 \mathrm{H}), 7.42-7.38(\mathrm{~m}, 2 \mathrm{H}), 7.21(\mathrm{~d}, J=8.2 \mathrm{~Hz}, 1 \mathrm{H}), 2.76(\mathrm{~s}, 3 \mathrm{H})$.

${ }^{13} \mathrm{C}$ NMR $\left(75 \mathrm{MHz}, \mathrm{CDCl}_{3}\right) \delta(\mathrm{ppm}) 161.8,150.2,141.9,137.7,133.6,133.3,132.4,127.9,125.4,124.6,120.3$, $119.5,110.5,21.8$.

Elemental analysis: calcd (\%) for $\mathrm{C}_{14} \mathrm{H}_{10} \mathrm{BrNO}$ (288.14): C 58.36, H 3.50; found: C 58.14, H 3.88.

2-(5-Bromo-2-methoxyphenyl)benzofuran (26): Following the procedure A using benzofuran (295 $\mathrm{mg}, 2.5$ mmol) and 5-bromo-2-methoxybenzenesulfonyl chloride $(286 \mathrm{mg}, 1 \mathrm{mmol})$, the residue was purified by flash chromatography on silica gel $\left(\mathrm{SiO}_{2}\right.$, Pentane-AcOEt 85:15)to afford the desired compound 26 (188 $\left.\mathrm{mg}, 62 \%\right)$.

${ }^{1} \mathrm{H}$ NMR $\left(300 \mathrm{MHz}, \mathrm{CDCl}_{3}\right) \delta(\mathrm{ppm}) 8.20(\mathrm{~d}, J=2.6 \mathrm{~Hz}, 1 \mathrm{H}), 7.63(\mathrm{~d}, J=7.5 \mathrm{~Hz}, 1 \mathrm{H}), 7.54(\mathrm{~d}, J=7.7 \mathrm{~Hz}, 1 \mathrm{H})$, 7.41-7.35 (m, 2H), 7.34-7.23 (m, 2H), $6.81(\mathrm{~d}, J=8.8 \mathrm{~Hz}, 1 \mathrm{H}), 3.93(\mathrm{~s}, 3 \mathrm{H})$.

${ }^{13} \mathrm{C}$ NMR $\left(75 \mathrm{MHz}, \mathrm{CDCl}_{3}\right) \delta(\mathrm{ppm}) 107.4,110.9,112.6,113.2,121.1,121.3,122.8,124.6,129.4,129.5,131.5$, 150.6, 153.9, 155.4, 55.7.

Elemental analysis: calcd (\%) for $\mathrm{C}_{15} \mathrm{H}_{11} \mathrm{BrO}_{2}$ (303.16): C 59.43, $\mathrm{H}$ 3.66; found: $\mathrm{C} 59.23, \mathrm{H} 3.61$.

2-(5-Bromo-2-methoxyphenyl)-1-methylpyrrole (27): Following the procedure A using 1-methylpyrrole (203 $\mathrm{mg}, 2.5 \mathrm{mmol}$ ) and 5-bromo-2-methoxybenzenesulfonyl chloride $(286 \mathrm{mg}, 1 \mathrm{mmol})$, the residue was purified by flash chromatography on silica gel $\left(\mathrm{SiO}_{2}\right.$, Pentane-AcOEt 85:15) to afford the desired compound 27 (197 $\left.\mathrm{mg}, 74 \%\right)$.

${ }^{1} \mathrm{H}$ NMR $\left(400 \mathrm{MHz}, \mathrm{CDCl}_{3}\right) \delta(\mathrm{ppm}) 7.49-7.44(\mathrm{~m}, 2 \mathrm{H}), 6.87(\mathrm{~d}, J=8.2 \mathrm{~Hz}, 1 \mathrm{H}), 6.77(\mathrm{t}, J=2.3 \mathrm{~Hz}, 1 \mathrm{H}), 6.26(\mathrm{t}, J=$ $2.9 \mathrm{~Hz}, 1 \mathrm{H}), 6.20(\mathrm{dd}, J=2.0$ and $3.6 \mathrm{~Hz}, 1 \mathrm{H}), 3.83(\mathrm{~s}, 3 \mathrm{H}), 3.53(\mathrm{~s}, 3 \mathrm{H})$.

${ }^{13} \mathrm{C}$ NMR $\left(100 \mathrm{MHz}, \mathrm{CDCl}_{3}\right) \delta(\mathrm{ppm}) 156.4,134.6,131.5,129.5,124.6,122.9,112.5,112.4,109.4,107.6,55.6,34.5$. Elemental analysis: calcd (\%) for $\mathrm{C}_{12} \mathrm{H}_{12} \mathrm{BrNO}$ (266.14): C 54.16, H 4.55; found: $\mathrm{C} 54.32, \mathrm{H} 4.38$.

2-(5-bromo-2-methoxyphenyl)benzoxazole (28): Following the procedure A using benzoxazole (298 $\mathrm{mg}, 2.5$ $\mathrm{mmol}$ ) and $\mathrm{CuI}(190 \mathrm{mg}, 1 \mathrm{mmol}), 5$-bromo-2-methoxybenzenesulfonyl chloride $(286 \mathrm{mg}, 1 \mathrm{mmol})$, the residue was purified by flash chromatography on silica gel $\left(\mathrm{SiO}_{2}\right.$, Pentane-AcOEt 85:15) to afford the desired compound 28 (116 $\mathrm{mg}, 38 \%)$.

${ }^{1} \mathrm{H}$ NMR $\left(400 \mathrm{MHz}, \mathrm{CDCl}_{3}\right) \delta(\mathrm{ppm}) 8.27(\mathrm{~d}, J=2.7 \mathrm{~Hz}, 1 \mathrm{H}), 7.85-7.81(\mathrm{~m}, 1 \mathrm{H}), 7.62-7.57(\mathrm{~m}, 2 \mathrm{H}), 7.40-7.33(\mathrm{~m}$, $2 \mathrm{H}), 6.98(\mathrm{~d}, J=9.1 \mathrm{~Hz}, 1 \mathrm{H}), 4.01(\mathrm{~s}, 3 \mathrm{H})$.

${ }^{13} \mathrm{C}$ NMR $\left(100 \mathrm{MHz}, \mathrm{CDCl}_{3}\right) \delta(\mathrm{ppm}) 159.9,157.5,135.3,133.6,125.4,124.5,120.4,117.9,113.9,112.8,110.5$, 56.5 .

Elemental analysis: calcd (\%) for $\mathrm{C}_{14} \mathrm{H}_{10} \mathrm{BrNO}_{2}$ (304.14): C 55.29, H 3.31; found: $\mathrm{C}$ 55.63, H 3.18.

2-(4-Methyl-3-(5-methylthiophen-3-yl)phenyl)benzoxazole (29): Following the procedure B using benzoxazole (298 $\mathrm{mg}, 2.5 \mathrm{mmol}$ ) and 4-(5-bromo-2-methylphenyl)-2-methylthiophene (22) (267 $\mathrm{mg}, 1 \mathrm{mmol})$, the residue was purified by flash chromatography on silica gel $\left(\mathrm{SiO}_{2}\right.$, Pentane-AcOEt 85:15) to afford the desired compound 29 (223 $\mathrm{mg}, 73 \%)$.

${ }^{1} \mathrm{H}$ NMR $\left(400 \mathrm{MHz}, \mathrm{CDCl}_{3}\right) \delta(\mathrm{ppm}) 8.19(\mathrm{~s}, 1 \mathrm{H}), 8.09(\mathrm{dd}, J=1.9$ and $7.9 \mathrm{~Hz}, 1 \mathrm{H}), 7.77(\mathrm{dd}, J=2.9 \mathrm{and} 4.5 \mathrm{~Hz}$, $1 \mathrm{H}), 7.58-7.54(\mathrm{~m}, 1 \mathrm{H}), 7.38(\mathrm{~d}, J=7.8 \mathrm{~Hz}, 1 \mathrm{H}), 7.36-7.321(\mathrm{~m}, 2 \mathrm{H}), 7.06(\mathrm{~s}, 1 \mathrm{H}), 6.82(\mathrm{~s}, 1 \mathrm{H}), 2.55(\mathrm{~s}, 3 \mathrm{H}), 2.43(\mathrm{~s}$, $3 \mathrm{H})$.

${ }^{13} \mathrm{C}$ NMR $\left(100 \mathrm{MHz}, \mathrm{CDCl}_{3}\right) \delta(\mathrm{ppm}) 163.1,150.6,142.1,140.8,139.7,139.5,137.6,131.1,128.7,127.0,126.1$, $124.9,124.7,124.5,121.0,119.8,110.4,21.0,15.3$.

Elemental analysis: calcd (\%) for $\mathrm{C}_{19} \mathrm{H}_{15} \mathrm{NOS}$ (305.40): C 74.73, H 4.95; found: C 74.62, H 5.12.

2-(4-methyl-3-(1-methylpyrrol-2-yl)phenyl)benzoxazole (30): Following the procedure $B$ using benzoxazole (298 $\mathrm{mg}, 2.5 \mathrm{mmol}$ ) and 2-(5-bromo-2-methylphenyl)-1-methylpyrrole (24) (250 $\mathrm{mg}, 1 \mathrm{mmol}$ ), the residue was purified by flash chromatography on silica gel $\left(\mathrm{SiO}_{2}\right.$, Pentane-AcOEt 85:15) to afford the desired compound 30 (228 mg, 79\%).

${ }^{1} \mathrm{H}$ NMR $\left(400 \mathrm{MHz}, \mathrm{CDCl}_{3}\right) \delta(\mathrm{ppm})$ 8.18-8.15 (m, 2H), 7.78-7.75 (m, 1H), 7.58-7.54 (m, 1H), $7.44(\mathrm{~d}, J=8.5 \mathrm{~Hz}$, $1 \mathrm{H}), 7.37-7.32(\mathrm{~m}, 2 \mathrm{H}), 6.75(\mathrm{dd}, J=1.8$ and $2.7 \mathrm{~Hz}, 1 \mathrm{H}), 6.25(\mathrm{dd}, J=2.7$ and $3.5 \mathrm{~Hz}, 1 \mathrm{H}), 6.15(\mathrm{dd}, J=1.8$ and $3.5 \mathrm{~Hz}, 1 \mathrm{H}), 3.47(\mathrm{~s}, 3 \mathrm{H}), 2.30(\mathrm{~s}, 3 \mathrm{H})$.

${ }^{13} \mathrm{C}$ NMR $\left(100 \mathrm{MHz}, \mathrm{CDCl}_{3}\right) \delta(\mathrm{ppm}) 163.0,150.7,142.3,142.1,134.0,132.0,130.7,130.3,126.9,124.9,124.6$, 124.5, 122.1, 119.9, 110.5, 109.0, 107.5, 34.2, 20.3.

Elemental analysis: calcd (\%) for $\mathrm{C}_{19} \mathrm{H}_{16} \mathrm{~N}_{2} \mathrm{O}$ (288.35): C 79.14, H 5.59; found: C 78.95, H 5.41.

2-(5-(4-ethyl-2-methylthiazol-5-yl)-2-methylphenyl)benzoxazole (32): Following the procedure B using 4ethyl-2-methylthiazole (318 mg, $2.5 \mathrm{mmol}$ ) and 2-(5-bromo-2-methylphenyl)benzoxazole (25) $(288 \mathrm{mg}, 1 \mathrm{mmol})$, the 
residue was purified by flash chromatography on silica gel $\left(\mathrm{SiO}_{2}\right.$, Pentane-AcOEt 85:15) to afford the desired compound 31 (281 mg, 84\%).

${ }^{1} \mathrm{H}$ NMR $\left(300 \mathrm{MHz}, \mathrm{CDCl}_{3}\right) \delta(\mathrm{ppm}) 8.23(\mathrm{~d}, J=1.9 \mathrm{~Hz}, 1 \mathrm{H}), 7.85-7.78(\mathrm{~m}, 1 \mathrm{H}), 7.63-7.58(\mathrm{~m}, 1 \mathrm{H}), 7.45(\mathrm{dd}, J=$ 1.9 ans $7.9 \mathrm{~Hz}, 1 \mathrm{H}), 7.40(\mathrm{~s}, 1 \mathrm{H}), 7.39-7.35(\mathrm{~m}, 2 \mathrm{H}), 3.03(\mathrm{q}, J=7.6 \mathrm{~Hz}, 2 \mathrm{H}), 2.84(\mathrm{~s}, 3 \mathrm{H}), 2.51(\mathrm{~s}, 3 \mathrm{H}), 1.42(\mathrm{t}, J=$ $7.6 \mathrm{~Hz}, 3 \mathrm{H})$.

${ }^{13} \mathrm{C}$ NMR $\left(75 \mathrm{MHz}, \mathrm{CDCl}_{3}\right) \delta(\mathrm{ppm}) 170.4,162.7,150.3,147.4,142.1,138.2,132.2,131.3,130.4,129.8,126.6$, $125.2,124.5,120.2,110.5,26.9,21.9,16.1,14.3$.

Elemental analysis: calcd (\%) for $\mathrm{C}_{20} \mathrm{H}_{18} \mathrm{~N}_{2} \mathrm{OS}$ (334.44): C 71.83, H 5.43; found: C 72.13, H 5.28.

4-Ethyl-5-(4-methoxy-3-(1-methylpyrrol-2-yl)phenyl)-2-methylthiazole (32): Following the procedure B using 4-ethyl-2-methylthiazole (318 mg, $2.5 \mathrm{mmol})$ and 2-(5-bromo-2-methoxyphenyl)-1-methylpyrrole (27) (266 mg, 1 $\mathrm{mmol})$, the residue was purified by flash chromatography on silica gel $\left(\mathrm{SiO}_{2}\right.$, Pentane-AcOEt 80:20) to afford the desired compound 32 (247 $\mathrm{mg}, 79 \%)$.

${ }^{1} \mathrm{H}$ NMR $\left(300 \mathrm{MHz}, \mathrm{CDCl}_{3}\right) \delta(\mathrm{ppm}) 7.43-7.34(\mathrm{~m}, 2 \mathrm{H}), 6.99(\mathrm{~d}, J=8.5 \mathrm{~Hz}, 1 \mathrm{H}), 6.75(\mathrm{dd}, J=1.8$ and $2.8 \mathrm{~Hz}, 1 \mathrm{H})$, $6.24(\mathrm{dd}, J=2.8$ and $3.5 \mathrm{~Hz}, 1 \mathrm{H}), 6.18(\mathrm{dd}, J=1.8$ and $3.5 \mathrm{~Hz}, 1 \mathrm{H}), 3.85(\mathrm{~s}, 3 \mathrm{H}), 3.54(\mathrm{~s}, 3 \mathrm{H}), 3.01(\mathrm{q}, J=7.6 \mathrm{~Hz}$, $2 \mathrm{H}), 2.48(\mathrm{~s}, 3 \mathrm{H}), 1.41(\mathrm{t}, J=7.6 \mathrm{~Hz}, 3 \mathrm{H})$.

${ }^{13} \mathrm{C}$ NMR $\left(75 \mathrm{MHz}, \mathrm{CDCl}_{3}\right) \delta(\mathrm{ppm}) 169.6,156.7,146.4,132.9,130.4,130.3,129.7,124.7,122.8,122.7,110.8$, $109.2,107.6,55.5,34.6,26.9,16.0,14.3$.

Elemental analysis: calcd (\%) for $\mathrm{C}_{18} \mathrm{H}_{20} \mathrm{~N}_{2} \mathrm{OS}$ (312.43): C 69.20, H 6.45; found: C 69.47, H 6.59.

5-(3-(Benzofuran-2-yl)-4-methoxyphenyl)-4-ethyl-2-methylthiazole (33): Following the procedure B using 4ethyl-2-methylthiazole (318 mg, $2.5 \mathrm{mmol}$ ) and 2-(5-bromo-2-methoxyphenyl)benzofuran (26) $(303 \mathrm{mg}, 1 \mathrm{mmol}$ ), the residue was purified by flash chromatography on silica gel $\left(\mathrm{SiO}_{2}\right.$, Pentane-AcOEt 80:20) to afford the desired compound 33 (300 mg, 86\%).

${ }^{1} \mathrm{H}$ NMR $\left(300 \mathrm{MHz}, \mathrm{CDCl}_{3}\right) \delta(\mathrm{ppm}) 8.12(\mathrm{~d}, J=2.3 \mathrm{~Hz}, 1 \mathrm{H}), 7.61(\mathrm{dd}, J=1.5$ and $7.5 \mathrm{~Hz}, 1 \mathrm{H}), 7.52(\mathrm{~d}, J=7.5 \mathrm{~Hz}$, $1 \mathrm{H}), 7.40(\mathrm{~d}, J=0.9 \mathrm{~Hz}, 1 \mathrm{H}), 7.35(\mathrm{dd}, J=2.4$ and $8.5 \mathrm{~Hz}, 1 \mathrm{H}), 7.29(\mathrm{dt}, J=1.5$ and $7.0 \mathrm{~Hz}, 1 \mathrm{H}), 7.23(\mathrm{dt}, J=1.5$ and $7.0 \mathrm{~Hz}, 1 \mathrm{H}), 7.03(\mathrm{~d}, J=8.6 \mathrm{~Hz}, 1 \mathrm{H}), 4.03(\mathrm{~s}, 3 \mathrm{H}), 3.03(\mathrm{q}, J=7.6 \mathrm{~Hz}, 2 \mathrm{H}), 2.50(\mathrm{~s}, 3 \mathrm{H}), 1.43(\mathrm{t}, J=7.6 \mathrm{~Hz}$, $3 \mathrm{H})$

${ }^{13} \mathrm{C}$ NMR $\left(75 \mathrm{MHz}, \mathrm{CDCl}_{3}\right.$ ) $\delta(\mathrm{ppm}) 169.8,155.9,153.9,151.4,146.8,130.3,129.8,129.6,127.8,125.0,124.3$, $122.7,121.1,119.5,111.2,110.9,106.9,55.6,26.9,16.0,14.3$.

Elemental analysis: calcd (\%) for $\mathrm{C}_{21} \mathrm{H}_{19} \mathrm{NO}_{2} \mathrm{~S}$ (349.45): C 72.18, H 5.48; found: C 72.35, H 5.67.

\section{Acknowledgments}

We thank "Rennes Metropole", the CNRS, and French Scientific Ministry of Higher Education for providing financial support.

\section{References and notes}

1a) Hall, A.; Atkinson, S.; Brown, S. H.; Chessell, I. P.; Chowdhury, A.; Clayton, N. M.; Coleman, T.; Giblin, G. M. P.; Gleave, R. J.; Hammond, B.; Healy, M. P.; Johnson, M. R.; Michel, A. D.; Naylor, A.; Novelli, R.; Spalding, D. J.; Tang, S. P. Bioorg. Med. Chem. Lett. 2006, 16, 3657-3662; b) Hasvold, L. A.; Pratt, J.; McDaniel, K. F.; Sheppard, G. S.; Liu, D.; Elmore, S. W.; Hubbard, R. D.; AbbVie Inc., USA . US Patent, no. 20140275079, 2014; c) Bhardwaj, V.; Gumber, D.; Abbot, V.; Dhiman, S.; Sharma, P. RSC Adv. 2015, 5, 15233-15266.

2a) Meyers, J. K.; Rogers, B. N.; Groppi, V. E., Jr.; Piotrowski, D. W.; Bodnar, A. L.; Jacobsen, E. J.; Corbett, J. W.; Pharmacia \& Upjohn Company, USA; PCT Int. Appl., no. WO2002015662A2, 2002; b) Myers, J. K.; Rogers, B. N.; Groppi, V. E., Jr.; Piotrowski, D. W.; Bodnar, A. L.; Jacobsen, E. J.; Corbett, J. W.; Pharmacia \& Upjohn Company, USA; PCT Int. Appl., no. WO2002016355A2, 2002.

3 Selander, N.; J. Szabó, K. Chem. Rev. 2011, 111, 2048-2076.

4 Chan, A. K.-W.; Lam, E. S.-H.; Tam, A. Y.-Y.; Tsang, D. P.-K.; Lam, W. H.; Chan, M.-Y.; Wong, W.-T.; Yam, V. W.-W. Chem. Eur. J. 2013, 19, 13910-13924.

5a) Suzuki, T.; Tsubata, Y.; Obana, Y.; Fukushima, T.; Miyashi, T.; Saito, M.; Kawai, H.; Fujiwara, K.; Akiyama, K. Tetrahedron Lett. 2003, 44, 7881-7884; b) Ameerunisha Begum, M. S.; Seewald, O.; Floerke, U.; Henkel, G. Inorg. Chim. Acta 2008, 361, 1868-1874; c) Cheng, F.; Tang, N. Inorg. Chem. Commun. 2008, 11, 506-508; d) Mukhopadhyay, C.; Tapaswi, P. K. Tetrahedron Lett. 2008, 49, 6237-6240; e) Santella, J. B.; Gardner, D. S.; Yao, W.; Shi, C.; Reddy, P.; Tebben, A. J.; DeLucca, G. V.; Wacker, D. A.; Watson, P. S.; Welch, P. K.; Wadman, E. A.; Davies, P.; Solomon, K. A.; Graden, D. M.; Yeleswaram, S.; Mandlekar, S.; Kariv, I.; Decicco, C. P.; Ko, S. S.; Carter, P. H.; Duncia, J. V. Bioorg. Med. Chem. Lett. 2008, 18, 576-585; f) Jain, A. K.; Reddy, V. V.; Paul, A.; Muniyappa, K.; Bhattacharya, S. Biochemistry 2009, 48, 10693-10704; g) Mukhopadhyay, C.; Tapaswi, P. K.; Drew, 
M. G. B. Tetrahedron Lett. 2010, 51, 3944-3950; h) Azizi, N.; Dado, N.; Amiri, A. K. Can. J. Chem. 2012, 90, 195-198; i) Ban, X.; Jiang, W.; Sun, K.; Xie, X.; Peng, L.; Dong, H.; Sun, Y.; Huang, B.; Duan, L.; Qiu, Y. ACS Appl. Mater. Interfaces 2015, 7, 7303-7314.

6a) Mejia, M. L.; Agapiou, K.; Yang, X.; Holliday, B. J. J. Am. Chem. Soc. 2009, 131, 18196-18197; b) Hong, $\quad$ X.; Mellah, M.; Bordier, F.; Guillot, R.; Schulz, E. ChemCatChem 2012, 4, 1115-1121; c) Nguyen, M. T.; Holliday, B. J. Chem. Commun. 2015, 51, 8610-8613.

7a) van Haare, J. A. E. H.; van Boxtel, M.; Janssen, R. A. J. Chem. Mater. 1998, 10, 1166-1175; b) Ishikawa, $\quad$ S.; Manabe, K. Chem. Lett. 2007, 36, 1304-1305; c) Cornacchio, A. L. P.; Price, J. T.; Jennings, M. C.; McDonald, R.; Staroverov, V. N.; Jones, N. D. J. Org. Chem. 2009, 74, 530-544; d) Idzik, K. R.; Beckert, R.; Golba, S.; Ledwon, P.; Lapkowski, M. Tetrahedron Lett. 2010, 51, 2396-2399; e) Xia, J.; Yuan, S.; Wang, Z.; Kirklin, S.; Dorney, B.; Liu, D.-J.; Yu, L. Macromolecules 2010, 43, 3325-3330; f) Bolliger, J. L.; Frech, C. M. Chem. Eur. J. 2010, 16, 11072-11081; g) Konidena, R. K.; Thomas, K. R. J.; Kumar, S.; Wang, Y.-C.; Li, C.-J.; Jou, J.-H. J. Org. Chem. 2015, 80, 5812-5823.

8a) Sinclair, D. J.; Sherburn, M. S. J. Org. Chem. 2005, 70, 3730-3733; b) Guillén, E.; Hierrezuelo, J.; MartínezMallorquín, R.; López-Romero, J. M.; Rico, R. Tetrahedron 2011, 67, 2555-2561; c) Minard， C.; $\quad$ Palacio, $\quad$ C.; Cariou, K.; Dodd, R. H. Eur. J. Org. Chem. 2014, 2942-2955.

9 Beaumard, F.; Dauban, P.; Dodd, R. H. Org. Lett. 2009, 11, 1801-1804.

10a) Bellina, F.; Cauteruccio, S.; Rossi, R. Curr. Org. Chem. 2008, 12, 774-790; b) Kakiuchi, $\quad$ F.; $\quad$ Kochi, $\quad$ T. Synthesis 2008, 3013-3039; c) Ackermann, L.; Vicente, R.; Kapdi, A. R. Angew. Chem. Int. Ed. 2009, 48, $9792-$ 9826; d) Bellina, F.; Rossi, R. Chem. Rev. 2009, 110, 1082-1146; e) Bellina, F.; Rossi, R. Tetrahedron 2009, 65, 10269-10310; f) Chen, X.; Engle, K. M.; Wang, D.-H.; Yu, J.-Q. Angew. Chem. Int. Ed. 2009, 48, 5094-5115; g) Lyons, T. W.; Sanford, M. S. Chem. Rev. 2010,110, 1147-1169; h) Beck, E. M.; Gaunt, M. J. Top. Curr. Chem. 2010, 292, 85-121; i) Roger, J.; Gottumukkala, A. L.; Doucet, H. ChemCatChem 2010, 2, 20-40; j) Satoh, T.; Miura, M. Synthesis 2010, 3395-3409; k) Sun, C.-L.; Li, B.-J.; Shi, Z.-J. Chem. Commun. 2010, 46, 677-685; 1) Cho, S. H.; Kim, J. Y.; Kwak, J.; Chang, S. Chem. Soc. Rev. 2011, 40, 5068-5083; m) Kuhl, N.; Hopkinson, M. N.; Wencel-Delord, J.; Glorius, F. Angew. Chem. Int. Ed. 2012, 51, 10236-10254; n) Li, B.-J.; Shi, Z.-J. Chem. Soc. Rev. 2012, 41, 5588-5598; o) White, M. C. Synlett 2012, 23, 2746-2748; p) Kozhushkov, S. I.; Ackermann, L. Chem. Sci. 2013, 4, 886-896; q) He, M.; Soulé, J.-F.; Doucet, H. ChemCatChem 2014, 6, 1824-1859; r) Rossi, $\quad$ R.; Bellina, F.; Lessi, M.; Manzini, C. Adv. Synth. Catal. 2014, 356, 17-117; s) Yuan, K.; Soulé, J.-F.; Doucet, H. ACS Catal. 2015, 5, 978-991; t) Yadav, M. R.; Rit, R. K.; Shankar, M.; Sahoo, A. K. Asian J. Org. Chem. 2015, 4, 846864.

11a) Baloch, M.; Roy, R. J.; Roy, D.; Beydoun, K.; Doucet, H. RSC Adv. 2011, 1, 1527-1536; b) Chen, L.; Roger, J.; Bruneau, C.; Dixneuf, P. H.; Doucet, H. Chem. Commun. 2011, 47, 1872-1874; c) Fu, H. Y.; Doucet, H. Eur. J. Org. Chem. 2011, 7163-7173.

12 Zhao, X.; Dimitrijević, E.; Dong, V. M. J. Am. Chem. Soc. 2009, 131, 3466-3467.

13a) Zhang, M.; Zhang, S.; Liu, M.; Cheng, J. Chem. Commun. 2011, 47, 11522-11524; b) Jafarpour, F.; Olia, M. B. A.; Hazrati, H. Adv. Synth. Catal. 2013, 355, 3407-3412; c) Yuan, K.; Doucet, H. Chem. Sci. 2014, 5, 392-396; d) Beladhria, A.; Yuan, K.; Ben Ammar, H.; Soulé, J.-F.; Ben Salem, R.; Doucet, H. Synthesis 2014, 46, 2515-2523; e) Loukotova, L.; Yuan, K.; Doucet, H. ChemCatChem 2014, 6, 1303-1309; f) Jin, R.; Yuan, K.; Chatelain, E.; Soulé, J.-F.; Doucet, H. Adv. Synth. Catal. 2014, 356, 3831-3841; g) Zhang, W.; Liu, F.; Zhao, B. Appl. Organomet. Chem. 2015, 29, 524-527.

14a) Chen, R.; Liu, S.; Liu, X.; Yang, L.; Deng, G.-J. Org. Biomol. Chem. 2011, 9, 7675-7679; b) Wang, M.; Li, D.; Zhou, W.; Wang, L. Tetrahedron 2012, 68, 1926-1930; c) Liu, B.; Guo, Q.; Cheng, Y.; Lan, J.; You, J. Chem. Eur. J. 2011, 17, 13415-13419; d) Wang, S.; Liu, W.; Lin, J.; Jiang, Y.; Zhang, Q.; Zhong, Y. Synlett 2014, 25, 586-590; e) Wu, M.; Luo, J.; Xiao, F.; Zhang, S.; Deng, G.-J.; Luo, H.-A. Adv. Synth. Catal. 2012, 354, 335-340; f) Miao, T.; Li, P.; Wang, G.-W.; Wang, L. Chem. Asian J. 2013, 8, 3185-3190.

15a) Yu, X.; Li, X.; Wan, B. Org. Biomol. Chem. 2012, 10, 7479-7482; b) Yuen, O. Y.; So, C. M.; Wong, W. T.; Kwong, F. Y. Synlett 2012, 23, 2714-2718.

16 Skhiri, A.; Beladhria, A.; Yuan, K.; Soulé, J.-F.; Ben Salem, R.; Doucet, H. Eur. J. Org. Chem. 2015, 4428-4436. 17 Soulé, J.-F.; Doucet, H. In New Arylating Agents in Pd-Catalyzed C-H Bond Functionalization of 5-Membered Ring Heteroarenes; Springer Berlin Heidelberg, 2016. (in press).

18 Hfaiedh, A.; Yuan, K.; Ben Ammar, H.; Ben Hassine, B.; Soulé, J.-F.; Doucet, H. ChemSusChem 2015, 8, 17941804.

19 Suprisingly, the arenesulfonyl chloride $\mathbf{1}$ is quite stable and could be purified over regular silica gel without hydrolysis of the sulfonyl chloride function.

20 Belkessam, F.; Mohand, A.; Soulé, J.-F.; Elias, A.; Doucet, H. Beilstein J. Org. Chem. 2014, 10, 2912-2919. 
21 Makrecka, M.; Zalubovskis, R.; Vavers, E.; Ivanova, J.; Grandane, A.; Dambrova, M. Lett. Drug Des. Discov. 2013, 10, 410-414.

22 Cantat, T.; Génin, E.; Giroud, C.; Meyer, G.; Jutand, A. J. Organomet. Chem. 2003, 687, 365-376.

23 Nadres, E. T.; Lazareva, A.; Daugulis, O. J. Org. Chem. 2011, 76, 471-483.

24 Li, Y.; Cheng, L.; Liu, X.; Li, B.; Sun, N. Beilstein J. Org. Chem. 2014, 10, 2886-2891. 